4

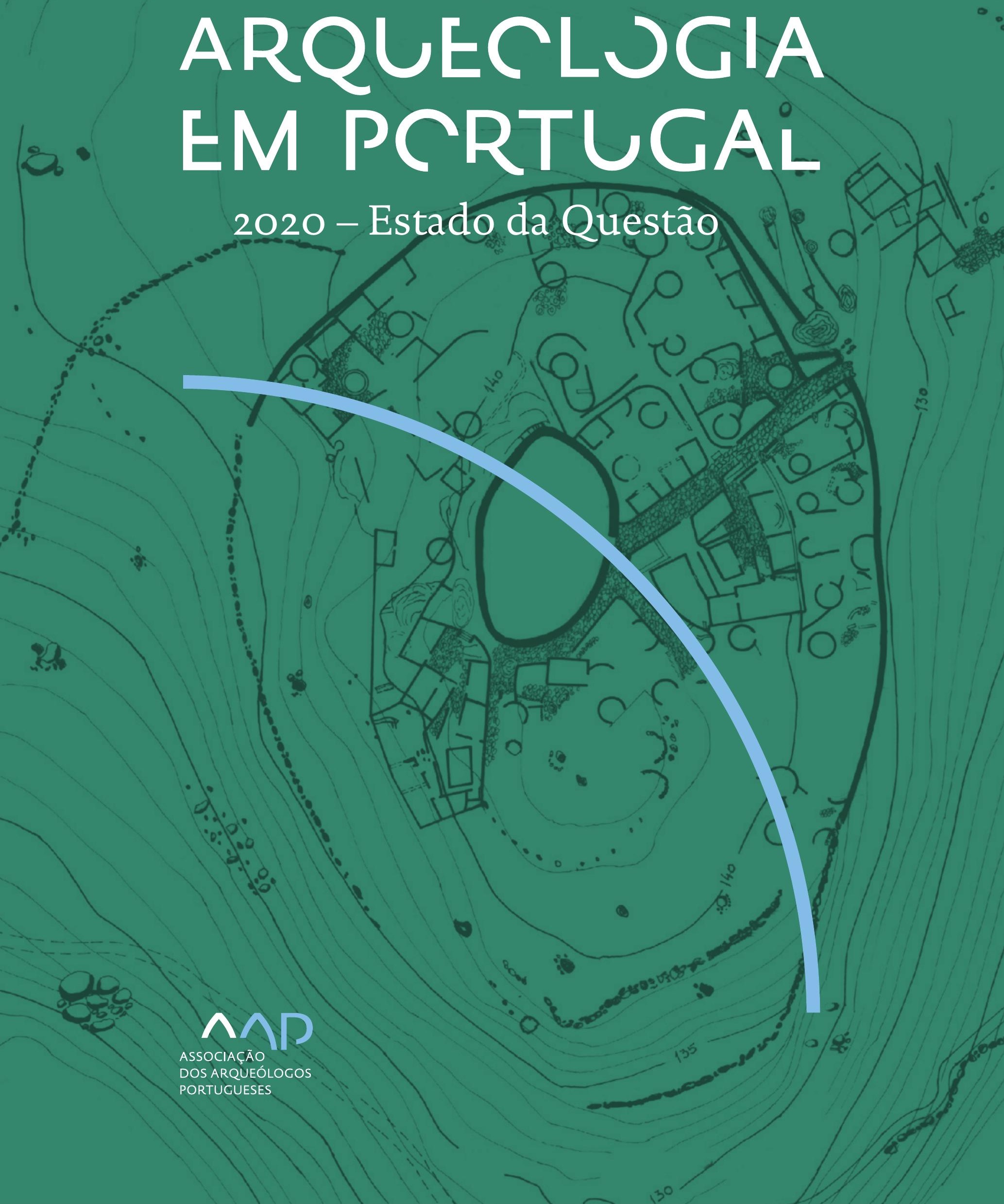


Coordenação editorial: José Morais Arnaud, César Neves e Andrea Martins Design gráfico: Flatland Design

AAP - ISBN: 978-972-9451-89-8

CITCEM - ISBN: 978-989-8970-25-1

Associação dos Arqueólogos Portugueses e CITCEM

Lisboa, 2020

O conteúdo dos artigos é da inteira responsabilidade dos autores. Sendo assim a Associação dos Arqueólogos Portugueses declina qualquer responsabilidade por eventuais equívocos ou questões de ordem ética e legal.

Desenho de capa:

Planta do castro de Monte Mozinho (Museu Municipal de Penafiel).

\section{$\hat{\wedge} \mathrm{P}$}

DOS ARQUEÓLOGOS PORTUGUESES

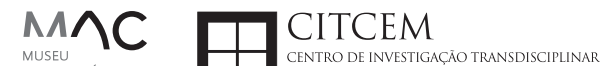
MUSEU
ARQUELLÓGICO
DO CARMO
U.PORTO

FLUP FACULDADE DE LETRAS
UNIVERSIDADE DO PORTO

Apoio

EC para a Ciência 


\section{Índice}

15 Prefácio

José Morais Arnaud

\section{Historiografia e Teoria}

17 Território, comunidade, memória e emoção: a contribuição da história da arqueologia (algumas primeiras e breves reflexões)

Ana Cristina Martins

25 Como descolonizar a arqueologia portuguesa?

Rui Gomes Coelho

41 Arqueologia e Modernidade: uma revisitação pessoal e breve de alguns aspetos da obra homónima de Julian Thomas de 2004

Vítor Oliveira Jorge

57 Dados para a História das Mulheres na Arqueologia portuguesa, dos finais do século XIX aos inícios do século XX: números, nomes e tabelas

Filipa Dimas / Mariana Diniz

73 Retractos da arqueologia portuguesa na imprensa: (in)visibilidades no feminino

Catarina Costeira / Elsa Luís

85 Arqueologia e Arqueólogos no Norte de Portugal Jacinta Bugalhão

101 Vieira Guimarães (1864-1939) e a arqueologia em Tomar: uma abordagem sobre o território e as gentes

João Amendoeira Peixoto / Ana Cristina Martins

115 Os memoráveis? A arqueologia algarvia na imprensa nacional e regional na presente centúria (2001-2019): características, visões do(s) passado(s) e a arqueologia

enquanto marca

Frederico Agosto / João Silva

129 A Evolução da Arqueologia Urbana e a Valorização Patrimonial no Barlavento Algarvio: Os casos de Portimão e Silves

Artur Mateus / Diogo Varandas / Rafael Boavida

\section{Gestão, Valorização e Salvaguarda do Património}

145 O Caderno Reivindicativo e as condições de trabalho em Arqueologia Miguel Rocha / Liliana Matias Carvalho / Regis Barbosa / Mauro Correia / Sara Simões / Jacinta Bugalhão / Sara Brito / Liliana Veríssimo Carvalho / Richard Peace / Pedro Peça / Cézer Santos

155 Os Estudos de Impacte Patrimonial como elemento para uma estratégia sustentável de minimização de impactes no âmbito de reconversões agrícolas Tiago do Pereiro

165 Salvaguarda de Património arqueológico em operações florestais: gestão e sensibilização Filipa Bragança / Gertrudes Zambujo / Sandra Lourenço / Belém Paiva / Carlos Banha / Frederico Tatá Regala / Helena Moura / Jacinta Bugalhão / João Marques / José Correia / Pedro Faria / Samuel Melro

179 Os valores do Património: uma investigação sobre os Sítios Pré-históricos de Arte Rupestre do Vale do Rio Côa e de Siega Verde José Paulo Francisco 
189 Conjugando recursos arqueológicos e naturais para potenciar as visitas ao Geoparque Litoral de Viana do Castelo (Noroeste de Portugal)

Hugo A. Sampaio / Ana M.S. Bettencourt / Susana Marinho / Ricardo Carvalhido

203 Áreas de Potencial Arqueológico na Região do Médio Tejo: Modelo Espacial Preditivo Rita Ferreira Anastácio / Ana Filipa Martins / Luiz Oosterbeek

223 Património Arqueológico e Gestão Territorial: O contributo da Arqueologia para a revisão do PDM de Avis

Ana Cristina Ribeiro

237 A coleção arqueológica do extinto Museu Municipal do Porto - Origens, Percursos e Estudos

Sónia Couto

251 Valpaços - uma nova carta arqueológica

Pedro Pereira / Maria de Fátima Casares Machado

263 Arqueologia na Cidade de Peniche

Adriano Constantino / Luís Rendeiro

273 Arqueologia Urbana: a cidade de Lagos como caso de Estudo Cátia Neto

285 Estratégias de promoção do património cultural subaquático nos Açores. O caso da ilha do Faial

José Luís Neto / José Bettencourt / Luís Borges / Pedro Parreira

297 Carta Arqueológica da Cidade Velha: Uma primeira abordagem

Jaylson Monteiro / Nireide Tavares / Sara da Veiga / Claudino Ramos / Edson Brito /

Carlos Carvalho / Francisco Moreira / Adalberto Tavares

311 Antropologia Virtual: novas metodologias para a análise morfológica e funcional Ricardo Miguel Godinho / Célia Gonçalves

\section{Didáctica da Arqueologia}

327 Como os projetos de Arqueologia podem contribuir para uma comunidade culturalmente mais consciente Alexandra Figueiredo / Claúdio Monteiro / Adolfo Silveira / Ricardo Lopes

337 Educação Patrimonial - Um cidadão esclarecido é um cidadão ativo! Ana Paula Almeida

351 A aproximação da Arqueologia à sala de aula: um caso de estudo no $3^{\circ}$ ciclo do Ensino Básico Luís Serrão Gil

363 Arqueologia 3.o - Pensar e comunicar a Arqueologia para um futuro sustentável Mónica Rolo

377 “Conversa de Arqueólogos" - Divulgar a Arqueologia em tempos de Pandemia Diogo Teixeira Dias

389 Escola Profissional de Arqueologia: desafios e oportunidades Susana Nunes / Dulcineia Pinto / Júlia Silva / Ana Mascarenhas

399 Os Museus de Arqueologia e os Jovens: a oferta educativa para o público adolescente Beatriz Correia Barata / Leonor Medeiros

411 O museu universitário como mediador entre a ciência e a sociedade: o exemplo da secção de arqueologia no Museu de História Natural e da Ciência da Universidade do Porto (MHNC-UP)

Rita Gaspar 
421 Museu de Lanifícios: Real Fábrica de Panos. Atividades no âmbito da Arqueologia Beatriz Correia Barata / Rita Salvado

427 Arqueologia Pública e o caso da localidade da Mata (Torres Novas) Cláudia Manso / Ana Rita Ferreira / Cristiana Ferreira / Vanessa Cardoso Antunes

431 Do sítio arqueológico ao museu: um percurso (também) didático Lídia Fernandes

447 Estão todos convidados para a Festa! E para dançar também... O projecto do Serviço Educativo do Museu Arqueológico do Carmo na $5^{\underline{a}}$ Edição da Festa da Arqueologia Rita Pires dos Santos

459 O “Clã de Carenque”, um projeto didático de arqueologia Eduardo Gonzalez Rocha

469 Mediação cultural: peixe que puxa carroça nas Ruínas Romanas de Troia Inês Vaz Pinto / Ana Patrícia Magalhães / Patrícia Brum / Filipa Santos

481 Didática Arqueológica, experiências do Projeto Mértola Vila Museu Maria de Fátima Palma / Clara Rodrigues / Susana Gómez / Lígia Rafael

\section{Arte Rupestre}

497 Os inventários de arte rupestre em Portugal Mila Simões de Abreu

513 O projeto FIRST-ART - conservação, documentação e gestão das primeiras manifestações de arte rupestre no Sudoeste da Península Ibérica: as grutas do Escoural e Maltravieso Sara Garcês / Hipólito Collado / José Julio García Arranz / Luiz Oosterbeek / António Carlos Silva / Pierluigi Rosina / Hugo Gomes / Anabela Borralheiro Pereira / George Nash / Esmeralda Gomes / Nelson Almeida / Carlos Carpetudo

523 Trabalhos de documentação de arte paleolítica realizados no âmbito do projeto PalæoCôa André Tomás Santos / António Fernando Barbosa / Luís Luís / Marcelo Silvestre / Thierry Aubry

537 Imagens fantasmagóricas, silhuetas elusivas: as figuras humanas na arte do Paleolítico Superior da região do Côa Mário Reis

$55^{1}$ Os motivos zoomórficos representados nas placas de tear de Vila Nova de São Pedro (Azambuja, Portugal) Andrea Martins / César Neves / José M. Arnaud / Mariana Diniz

571 Arte Rupestre do Monte de Góios (Lanhelas, Caminha). Síntese dos resultados dos trabalhos efectuados em 2007-2009 Mário Varela Gomes

599 Gravuras rupestres de barquiformes no Monte de S. Romão, Guimarães, Noroeste de Portugal Daniela Cardoso

613 Círculos segmentados gravados na Bacia do Rio Lima (Noroeste de Portugal): contributos para o seu estudo Diogo Marinho / Ana M.S. Bettencourt / Hugo Aluai Sampaio

631 Equídeos gravados no curso inferior do Rio Mouro, Monção (NW Portugal). Análise preliminar Coutinho, L.M. / Bettencourt, A.M.S / Sampaio, Hugo A.S

645 Paletas na Arte Rupestre do Noroeste de Portugal. Inventário preliminar Bruna Sousa Afonso / Ana M. S. Bettencourt / Hugo A. Sampaio 


\section{Pré-História}

661 O projeto Miño/Minho: balanço de quatro anos de trabalhos arqueológicos Sérgio Monteiro-Rodrigues / João Pedro Cunha-Ribeiro / Eduardo Méndez-Quintas / Carlos Ferreira / Pedro Xavier / José Meireles / Alberto Gomes / Manuel Santonja / Alfredo Pérez-González

677 A ocupação paleolítica da margem esquerda do Baixo Minho: a indústria lítica do sítio de Pedreiras 2 (Monção, Portugal) e a sua integração no contexto regional Carlos Ferreira / João Pedro Cunha-Ribeiro / Sérgio Monteiro-Rodrigues / Eduardo Méndez-Quintas / Pedro Xavier / José Meireles / Alberto Gomes / Manuel Santonja / Alfredo Pérez-González

693 O sítio acheulense do Plistocénico médio da Gruta da Aroeira Joan Daura / Montserrat Sanz / Filipa Rodrigues / Pedro Souto / João Zilhão

703 As sociedades neandertais no Barlavento algarvio: modelos preditivos com recurso aos SIG

Daniela Maio

715 A utilização de quartzo durante o Paleolítico Superior no território dos vales dos rios Vouga e Côa

Cristina Gameiro / Thierry Aubry / Bárbara Costa / Sérgio Gomes / Luís Luís / Carmen Manzano / André Tomás Santos

733 Uma perspetiva diacrónica da ocupação do concheiro do Cabeço da Amoreira (Muge, Portugal) a partir da tecnologia lítica Joana Belmiro / João Cascalheira / Célia Gonçalves

745 Novos dados sobre a Pré-história Antiga no concelho de Palmela. A intervenção arqueológica no sítio do Poceirão I

Michelle Teixeira Santos

757 Problemas em torno de Datas Absolutas Pré-Históricas no Norte do Alentejo Jorge de Oliveira

771 Povoamento pré-histórico nas áreas montanhosas do NO de Portugal: o Abrigo 1 de Vale de Cerdeira Pedro Xavier / José Meireles / Carlos Alves

783 Apreciação do povoamento do Neolítico Inicial na Baixa Bacia do Douro. A Lavra I (Serra da Aboboreira) como caso de estudo Maria de Jesus Sanches

797 O Processo de Neolitização na Plataforma do Mondego: os dados do Sector C do Outeiro dos Castelos de Beijós (Carregal do Sal)

João Carlos de Senna-Martinez / José Manuel Quintã Ventura / Andreia Carvalho / Cíntia Maurício

823 Novos trabalhos na Lapa da Bugalheira (Almonda, Torres Novas) Filipa Rodrigues / Pedro Souto / Artur Ferreira / Alexandre Varanda / Luís Gomes / Helena Gomes / João Zilhão

837 A pedra polida e afeiçoada do sítio do Neolítico médio da Moita do Ourives (Benavente, Portugal)

César Neves

857 Casal do Outeiro (Encarnação, Mafra): novos contributos para o conhecimento do povoamento do Neolítico final na Península de Lisboa.

Cátia Delicado / Carlos Maneira e Costa / Marta Miranda / Ana Catarina Sousa

873 Stresse infantil, morbilidade e mortalidade no sítio arqueológico do Neolítico Final/ Calcolítico ( $4^{\circ}$ e $3^{\circ}$ milénio a.C.) do Monte do Carrascal 2 (Ferreira do Alentejo, Beja) Liliana Matias de Carvalho / Sofia N. Wasterlain 
885 Come together: O Conjunto Megalítico das Motas (Monção, Viana do Castelo) e as expressões Campaniformes do Alto Minho Ana Catarina Basílio / Rui Ramos

899 Trabalhos arqueológicos no sítio Calcolítico da Pedreira do Poio Carla Magalhães / João Muralha / Mário Reis / António Batarda Fernandes

913 O sítio arqueológico de Castanheiro do Vento. Da arquitectura do sítio à arquitectura de um território João Muralha Cardoso

925 Estudo zooarqueológico das faunas do Calcolítico final de Vila Nova de São Pedro (Azambuja, Portugal): Campanhas de 2017 e 2018 Cleia Detry / Ana Catarina Francisco / Mariana Diniz / Andrea Martins / César Neves / José Morais Arnaud

943 As faunas depositadas no Museu Arqueológico do Carmo provenientes de Vila Nova de São Pedro (Azambuja): as campanhas de 1937 a 1967 Ana Catarina Francisco / Cleia Detry / César Neves / Andrea Martins / Mariana Diniz / José Morais Arnaud

959 Análise funcional de material lítico em sílex do castro de Vila Nova de S. Pedro (Azambuja, Portugal): uma primeira abordagem Rafael Lima

971 O recinto da Folha do Ouro 1 (Serpa) no contexto dos recintos de fossos calcolíticos alentejanos

António Carlos Valera / Tiago do Pereiro / Pedro Valério / António M. Monge Soares

\section{Proto-História}

987 Produção de sal marinho na Idade do Bronze do noroeste Português. Alguns dados para uma reflexão

Ana M. S. Bettencourt / Sara Luz / Nuno Oliveira / Pedro P. Simões / Maria Isabel C. Alves / Emílio Abad-Vidal

1001 A estátua-menir do Pedrão ou de São Bartolomeu do Mar (Esposende, noroeste de Portugal) no contexto arqueológico da fachada costeira de entre os rios Neiva e Cávado Ana M. S. Bettencourt / Manuel Santos-Estévez / Pedro Pimenta Simões / Luís Gonçalves

1015 O Castro do Muro (Vandoma/Baltar, Paredes) - notas para uma biografia de ocupação da Idade do Bronze à Idade Média

Maria Antónia D. Silva / Ana M. S. Bettencourt / António Manuel S. P. Silva / Natália Félix

1031 Do Bronze Final à Idade Média - continuidades e hiatos na ocupação de Povoados em Oliveira de Azeméis João Tiago Tavares / Adriaan de Man

1041 As faunas do final da Idade do Bronze no Sul de Portugal: leituras desde o Outeiro do Circo (Beja)

Nelson J. Almeida / Íris Dias / Cleia Detry / Eduardo Porfírio / Miguel Serra

1055 A Espada do Monte das Oliveiras (Serpa) - uma arma do Bronze Pleno do Sudoeste Rui M. G. Monge Soares / Pedro Valério / Mariana Nabais / António M. Monge Soares

1065 São Julião da Branca (Albergaria-a-Velha) - Investigação e valorização de um povoado do Bronze Final

António Manuel S. P. Silva / Paulo A. P. Lemos / Sara Almeida e Silva / Edite Martins de Sá

1083 Do castro de S. João ao Mosteiro de Santa Clara: notícia de uma intervenção arqueológica, em Vila do Conde Rui Pinheiro 
1095 O castro de Ovil (Espinho), um quarto de século de investigação - resultados e questões em aberto

Jorge Fernando Salvador / António Manuel S. P. Silva

1111 O Castro de Salreu (Estarreja), um povoado proto-histórico no litoral do Entre Douro e Vouga

Sara Almeida e Silva / António Manuel S. P. Silva / Paulo A. P. Lemos / Edite Martins de Sá

1127 Castro de Nossa Senhora das Necessidades (Sernancelhe): uma primeira análise artefactual Telma Susana O. Ribeiro

${ }_{1141}$ A cividade de Bagunte. O estado atual da investigação Pedro Brochado de Almeida

1153 Zoomorfos na cerâmica da Idade do Ferro no NW Peninsular: inventário, cronologias e significado Nuno Oliveira / Cristina Seoane

1163 Vasos gregos em Portugal: diferentes maneiras de contar a história do intercâmbio cultural na Idade do Ferro

Daniela Ferreira

1175 Os exotica da necrópole da Idade do Ferro do Olival do Senhor dos Mártires (Alcácer do Sal) no seu contexto regional

Francisco B. Gomes

\section{Antiguidade Clássica e Tardia}

1191 O uso de madeira como combustível no sítio da Quinta de Crestelos (Baixo Sabor): da Idade do Ferro à Romanização Filipe Vaz / João Tereso / Sérgio Simões Pereira / José Sastre / Javier Larrazabal Galarza / Susana Cosme / José António Pereira / Israel Espi

1207 Cultivos de Época Romana no Baixo Sabor: continuidade em tempos de mudança? João Pedro Tereso / Sérgio Simões Pereira / Filipe Santos / Luís Seabra / Filipe Vaz

1221 A casa romana na Hispânia: aplicação dos modelos itálicos nas províncias ibéricas Fernanda Magalhães / Diego Machado / Manuela Martins

1235 As pinturas murais romanas da Rua General Sousa Machado, n. ${ }^{5}$ 1, Chaves José Carvalho

1243 Trás do Castelo (Vale de Mir, Pegarinhos, Alijó) - Uma exploração agrícola romana do Douro

Tony Silvino / Pedro Pereira

1255 A sequência de ocupação no quadrante sudeste de Bracara Augusta: as transformações de uma unidade doméstica Lara Fernandes / Manuela Martins

1263 Os Mosaicos com decoração geométrica e geométrico-vegetalista dos sítios arqueológicos da área do Conuentus Bracaraugustanus. Novas abordagens quanto à conservação, restauro, decoração e datação Maria de Fátima Abraços / Licínia Wrench

1277 “Casa Romana” do Castro de São Domingos (Cristelos, Lousada): Escavação, Estudo e Musealização Paulo André de P. Lemos

1291 A arqueobotânica no Castro de Guifões (Matosinhos, Noroeste de Portugal): O primeiro estudo carpológico

Luís Seabra / Andreia Arezes / Catarina Magalhães / José Varela / João Pedro Tereso 
1305 Um Horreum Augustano na Foz do Douro (Monte do Castelo de Gaia, Vila Nova de Gaia) Rui Ramos

1311 Ponderais romanos na Lusitânia: padrões, formas, materiais e contextos de utilização Diego Barrios Rodríguez

1323 Um almofariz centro-itálico na foz do Mondego

Marco Penajoia

1335 Estruturas romanas de Carnide - Lisboa Luísa Batalha / Mário Monteiro / Guilherme Cardoso

1347 O contexto funerário do sector da "necrópole NO" da Rua das Portas de S. Antão (Lisboa): o espaço, os artefactos, os indivíduos e a sua interconectividade na interpretação do passado Sílvia Loja, José Carlos Quaresma, Nelson Cabaço, Marina Lourenço, Sílvia Casimiro, Rodrigo Banha da Silva, Francisca Alves-Cardoso

${ }_{1361}$ Povoamento em época Romana na Amadora - resultados de um projeto pluridisciplinar Gisela Encarnação / Vanessa Dias

1371 A Arquitectura Residencial em Mirobriga (Santiago do Cacém): contributo a partir de um estudo de caso Filipe Sousa / Catarina Felício

${ }_{1385}$ O fim do ciclo. Saneamento e gestão de resíduos nos edifícios termais de Mirobriga (Santiago do Cacém)

Catarina Felício / Filipe Sousa

1399 Balsa, Topografia e Urbanismo de uma Cidade Portuária Vítor Silva Dias / João Pedro Bernardes / Celso Candeias / Cristina Tété Garcia

1413 No Largo das Mouras Velhas em Faro (2017): novas evidências da necrópole norte de Ossonoba e da sua ocupação medieval Ricardo Costeira da Silva / Paulo Botelho / Fernando Santos / Liliana Nunes

1429 Instrumentos de pesca recuperados numa fábrica de salga em Ossonoba (Faro) Inês Rasteiro / Ricardo Costeira da Silva / Paulo Botelho

1439 A Necrópole Romana do Eirô, Duas Igrejas (Penafiel): intervenção arqueológica de 2016 Laura Sousa / Teresa Soeiro

1457 Ritual, descarte ou afetividade? A presença de Canis lupus familiaris na Necrópole Noroeste de Olisipo (Lisboa)

Beatriz Calapez Santos / Sofia Simões Pereira / Rodrigo Banha da Silva / Sílvia Casimiro / Cleia Detry / Francisca Alves Cardoso

1467 Dinâmicas económicas em Bracara na Antiguidade Tardia Diego Machado / Manuela Martins / Fernanda Magalhães / Natália Botica

1479 Cerâmicas e Vidros da Antiguidade Tardia do Edifício sob a Igreja do Bom Jesus (Vila Nova de Gaia) Joaquim Filipe Ramos

1493 Novos contributos para a topografia histórica de Mértola no período romano e na Antiguidade Tardia Virgílio Lopes

\section{8. Época Medieval}

1511 Cerâmicas islâmicas no Garb setentrional "português": algumas evidências e incógnitas Constança dos Santos / Helena Catarino / Susana Gómez / Maria José Gonçalves / Isabel Inácio / Gonçalo Lopes / Jacinta Bugalhão / Sandra Cavaco / Jaquelina Covaneiro / Isabel Cristina Fernandes / Ana Sofia Gomes 
1525 Contributo para o conhecimento da cosmética islâmica, em Silves, durante a Idade Média Rosa Varela Gomes

1537 Yábura e o seu território - uma análise histórico-arqueológica de Évora entre os séculos VIII-XII José Rui Santos

1547 A encosta sul do Castelo de Palmela - resultados preliminares da escavação arqueológica Luís Filipe Pereira / Michelle Teixeira Santos

1559 A igreja de São Lourenço (Mouraria, Lisboa): um conjunto de silos e de cerâmica medieval islâmica

Andreia Filipa Moreira Rodrigues

1571 O registo material de movimentações populacionais no Médio Tejo, durante os séculos XII-XIII. Dois casos de "sunken featured buildings", nos concelhos de Cartaxo e Torres Novas Marco Liberato / Helena Santos / Nuno Santos

1585 O nordeste transmontano nos alvores da Idade média. Notas para reflexão Ana Maria da Costa Oliveira

1601 Sepulturas escavadas na rocha do Norte de Portugal e do Vale do Douro: primeiros resultados do Projecto SER-NPVD

Mário Jorge Barroca / César Guedes / Andreia Arezes / Ana Maria Oliveira

1619 "Portucalem Castrum Novum" entre o Mediterrâneo e o Atlântico: o estudo dos materiais cerâmicos alto-medievais do arqueossítio da rua de D. Hugo, nํ. 5 (Porto) João Luís Veloso

1627 A Alta Idade Média na fronteira de Lafões: notas preliminares sobre a Arqueologia no Concelho de Vouzela

Manuel Luís Real / Catarina Tente

1641 Um conjunto cerâmico medieval fora de portas: um breve testemunho aveirense Susana Temudo

${ }_{1651}$ Os Lóios do Porto: uma perspetiva integrada no panorama funerário da Baixa Idade Média à Época Moderna em meios urbanos em Portugal

Ana Lema Seabra

1659 O Caminho Português Interior de Santiago como eixo viário na Idade Média Pedro Azevedo

1665 Morfologia Urbana: Um exercício em torno do Castelo de Ourém André Donas-Botto / Jaqueline Pereira

1677 Intervenção arqueológica na Rua Marquês de Pombal/Largo do Espírito Santo (Bucelas, Loures)

Florbela Estêvão / Nathalie Antunes-Ferreira / Dário Ramos Neves / Inês Lisboa

1691 O Cemitério Medieval do Poço do Borratém e a espacialidade funerária na cidade de Lisboa Inês Belém / Vanessa Filipe / Vasco Noronha Vieira / Sónia Ferro / Rodrigo Banha da Silva

1705 Um Espaço Funerário Conventual do séc. XV em Lisboa: o caso do Convento de São Domingos da Cidade Sérgio Pedroso / Sílvia Casimiro / Rodrigo Banha da Silva / Francisca Alves Cardoso

\section{9. Época Moderna e Contemporânea}

1721 Arqueologia Moderna em Portugal: algumas reflexões críticas em torno da quantificação de conjuntos cerâmicos e suas inferências históricas e antropológicas Rodrigo Banha da Silva / André Bargão / Sara da Cruz Ferreira

1733 Faianças de dois contextos entre os finais do século XVI e XVIII do Palácio dos Condes de Penafiel, Lisboa

Martim Lopes / Tomás Mesquita 
1747 Um perfil de consumo do século XVIII na foz do Tejo: O caso do Mercado da Ribeira, Lisboa Sara da Cruz Ferreira / Rodrigo Banha da Silva / André Bargão

1761 Os Cachimbos dos Séculos XVII e XVIII do Palácio Mesquitela e Convento dos Inglesinhos (Lisboa)

Inês Simão / Marina Pinto / João Pimenta / Sara da Cruz Ferreira / André Bargão / Rodrigo Banha da Silva

1775 "Tomar os fumos da erua que chamão em Portugal erua sancta». Estudo de Cachimbos provenientes da Rua do Terreiro do Trigo, Lisboa

Miguel Martins de Sousa / José Pedro Henriques / Vanessa Galiza Filipe

1787 Cachimbos de Barro Caulínitico da Sé da Cidade Velha (República de Cabo Verde)

Rodrigo Banha da Silva / João Pimenta / Clementino Amaro

1801 Algumas considerações sobre espólio não cerâmico recuperado no Largo de Jesus (Lisboa) Carlos Boavida

1815 Adereços de vidro, dos séculos XVI-XVIII, procedentes do antigo Convento de Santana de Lisboa (anéis, braceletes e contas)

Joana Gonçalves / Rosa Varela Gomes / Mário Varela Gomes

1837 Da ostentação, luxo e poder à simplicidade do uso quotidiano: arqueologia e simbologia de joias e adornos da Idade Moderna Portuguesa Jéssica Iglésias

1849 Os amuletos em Portugal - dos objetos às superstições: o coral vermelho Alexandra Vieira

1865 Cerâmicas de Vila Franca de Xira nos séculos XV e XVI Eva Pires

1879 «Não passa por teu o que me pertence». Marcas de individualização associadas a faianças do Convento de Nossa Senhora de Aracoeli, Alcácer do Sal Catarina Parreira / Íris Fragoso / Miguel Martins de Sousa

1891 Cerâmica de Leiria: alguns focos de produção

Jaqueline Pereira / André Donas-Botto

1901 Os Fornos na Rua da Biquinha, em Óbidos Hugo Silva / Filipe Oliveira

1909 A casa de Pêro Fernandes, contador dos contos de D. Manuel I: o sítio arqueológico da Silha do Alferes, Seixal (século XVI) Mariana Nunes Ferreira

1921 O Alto da Vigia (Sintra) e a vigilância e defesa da costa Alexandre Gonçalves / Sandra Santos

1937 O contexto da torre sineira da Igreja de Santa Maria de Loures Paulo Calaveira / Martim Lopes

1949 A Necrópole do Hospital Militar do Castelo de São Jorge e as práticas funerárias na Lisboa de Época Moderna Susana Henriques / Liliana Matias de Carvalho / Ana Amarante / Sofia N. Wasterlain

1963 SAND - Sarilhos Grandes Entre dois Mundos: o adro da Igreja e a Paleobiologia dos ossos humanos recuperados

Paula Alves Pereira / Roger Lee Jesus / Bruno M. Magalhães

1975 Expansão urbana da vila de Cascais no século XVII e XVIII: a intervenção arqueológica na Rua da Vitória no 15 a 17

Tiago Pereira / Vanessa Filipe

1987 Novos dados para o conhecimento do Urbanismo de Faro em época Moderna Ana Rosa 
1995 Um exemplo de Arqueologia Urbana em Alcoutim: o Antigo Edifício dos CTT Marco Fernandes / Marta Dias / Alexandra Gradim / Virgílio Lopes / Susana Gómez Martínez

2007 Palácio dos Ferrazes (Rua das Flores/Rua da Vitória, Porto): a cocheira de Domingos Oliveira Maia

Francisco Raimundo

2021 As muitas vidas de um edifício urbano: História, Arqueologia e Antropologia no antigo Recreatório Paroquial de Penafiel Helena Bernardo / Jorge Sampaio / Marta Borges

2035 O convento de Nossa Senhora da Esperança de Ponta Delgada: o contributo da arqueologia para o conhecimento de um monumento identitário João Gonçalves Araújo / N’Zinga Oliveira

2047 Arqueologia na ilha do Corvo... em busca da capela de Nossa Senhora do Rosário Tânia Manuel Casimiro / José Luís Neto / Luís Borges / Pedro Parreira

2059 Perdidos à vista da Costa. Trabalhos arqueológicos subaquáticos na Barra do Tejo Jorge Freire / José Bettencourt / Augusto Salgado

2071 Arqueologia marítima em Cabo Verde: enquadramento e primeiros resultados do projecto CONCHA

José Bettencourt / Adilson Dias / Carlos Lima / Christelle Chouzenoux / Cristóvão Fonseca / Dúnia Pereira / Gonçalo Lopes / Inês Coelho / Jaylson Monteiro / José Lima / Maria Eugénia Alves / Patrícia Carvalho / Tiago Silva

2085 Trabalhos arqueológicos na Cidade Velha (Ribeira Grande de Santiago, Cabo Verde): reflexões sobre um projecto de investigação e divulgação patrimonial André Teixeira / Jaylson Monteiro / Mariana Mateus / Nireide Tavares / Cristovão Fonseca / Gonçalo C. Lopes / Joana Bento Torres / Dúnia Pereira / André Bargão / Aurélie Mayer / Bruno Zélie / Carlos Lima / Christelle Chouzenoux / Inês Henriques / Inês Pinto Coelho / José Lima / Patrícia Carvalho / Tiago Silva

2103 A antiga fortificação de Quelba / Khor Kalba (E.A.U.). Resultados de quatro campanhas de escavações, problemáticas e perspectivas futuras Rui Carita / Rosa Varela Gomes / Mário Varela Gomes / Kamyar Kamyad

2123 Colónias para homens novos: arqueologia da colonização agrária fascista no noroeste ibérico Xurxo Ayán Vila / José Mạ . Señorán Martín 


\title{
OS MOSAICOS COM DECORAÇÃO GEOMÉTRICA E GEOMETRICO-VEGETALISTA DOS SÍTIOS ARQUEOLÓGICOS DA ÁREA DO CONUENTUS BRACARAUGUSTANUS. NOVAS ABORDAGENS QUANTO À CONSERVAÇÃO, RESTAURO, DECORAÇÃO E DATAÇÃO
}

\author{
Maria de Fátima Abraços, Licínia Wrench
}

\begin{abstract}
RESUMO
O presente estudo permite revisitar alguns dos mosaicos já apresentados no Corpus dos Mosaicos Romanos do Conuentus Bracaraugustanus (Hispania) publicado em Junho de 2019, pelo Centro de Estudos Históricos da Universidade NOVA de Lisboa, quanto à decoração e estado de conservação. Indicar-se-ão vários exemplos das decisões tomadas durante as intervenções arqueológicas quanto ao levantamento mosaístico e consequente diversificação de abordagens na apresentação e/ou documentação dos mosaicos em apreço, que na sua maioria se justificam devido a informações adicionais que resultaram do prosseguimento da nossa pesquisa e das que nos foram proporcionadas já depois da publicação do Corpus.

Palavras-chave: Conuentus Bracaraugustanus, Mosaicos romanos, Conservação, Restauro, Decoração.
\end{abstract}

\begin{abstract}
The present study allows us to revisit some of the mosaics already studied in the Corpus of Roman Mosaics of Conuentus Bracaraugustanus published in June 2019, by the Centro de Estudos Históricos da Universidade NOVA of Lisbon, regarding decoration and state of conservation. Examples of the decisions taken during archaeological interventions regarding the mosaic survey and the consequent diversification of approaches in the presentation and/or documentation of the mosaics under study will be indicated, which are mostly justified due to additional information that was known and was provided to us after the publication of the Corpus. Keywords: Conuentus Bracaraugustanus, Roman mosaics, Conservation, Restoration, Decoration.
\end{abstract}

\section{INTRODUÇÃO}

Os mosaicos descobertos nos diferentes sítios arqueológicos requerem medidas de conservação de modo a poderem subsistir aos diferentes ambientes a que vão ficar expostos ou acondicionados. $\mathrm{O}$ conhecimento antecipado dos factores de deterioração permite estabelecer planos direccionados para atenuar os seus efeitos, no sentido de proporcionar a salvaguarda destes bens. Assim os arqueólogos e técnicos de restauro tomam as suas decisões depois de um estudo prévio e podem decidir se os mosaicos ficam in situ, se são musealizados, se são reenterrados, e onde ficam acondicionados: nas reservas dos museus, nos depósitos de materiais arqueológicos ou outros. Tendo em conta esta metodologia, passamos a apresentar o modo como foram tratados neste artigo os mosaicos deste Conuentus. Para cada mosaico apresentamos as intervenções de conservação, restauro, musealização seguida da descrição dos elementos decorativos relevantes e datação.

Da totalidade dos noventa e três mosaicos pertencentes a trinta e sete sítios arqueológicos estudados no "Corpus dos Mosaicos Romanos do Conuentus 
Bracaraugustanus", seleccionámos alguns exemplos para os quais se manteve a numeração dos mosaicos analisados no Corpus, o número das páginas que o seu estudo ocupa e os sítios arqueológicos de onde provêm. Essa selecção foi efectuada consoante as informações adicionais que resultaram do prosseguimento da nossa pesquisa e das que nos foram proporcionadas já depois da publicação do Corpus. A grande maioria dos mosaicos provenientes do Conuentus Bracaraugustanus apresenta decoração geométrica e geometrico-vegetalista. Os poucos exemplares conhecidos com decoração figurativa, fauna aquática e vasos, provêm da cidade de Braga, mas foi também registado um mosaico com a representação de peixes no sítio arqueológico de Fonte do Milho, em Canelas (Peso da Régua), e a representação de um cantharus em uma tampa sepulcral encontrada no Lugar do Castelo, Frende, Baião (Marco de Canaveses). Seleccionaram-se os mosaicos cuja decoração e aspectos técnicos se consideraram significativos para a datação que lhes foi proposta, em diálogo com o contexto arqueológico em que se integravam. Em muitos casos, a datação resultante da análise estilístico-comparativa vai de encontro à datação proposta para os respectivos sítios arqueológicos, mas existem outros casos em que prevaleceram, ou os critérios estratigráficos, ou os estilísticos.

\section{MOSAICOS CONSERVADOS IN SITU MUSEALIZADOS}

\section{A - Mosaico da Domus da cripta do MDDS, Bra- cara Augusta/Eixo Interior}

Em 1991, durante a construção do edifício do Museu D. Diogo de Sousa, foram descobertas estruturas de uma domus que apresentava duas salas revestidas com mosaicos decorados com tabuleiro de xadrez e quadrícula de linhas de ampulhetas. (CMRCB, mosaico 1, pp. 47-54 - salas 1 e 2). Foi feito um isolamento especial desta área e foi também decidido que seria construído um novo edifício para albergar as novas estruturas. Tendo em conta as sucessivas inundações que ocorriam na área onde se encontravam os mosaicos situados ao nível friático, foi necessário e urgente proteger e enterrar novamente as estruturas, para que se realizasse com segurança a cobertura, que iria albergar os alicerces da domus. Em 1997, depois da construção do Bloco A, que alberga o espaço, onde se encontram os mosaicos, procedeu-se à remoção de todos os materiais de protecção usados quando do seu enterramento. Nesta altura, decidiu-se deixar ainda a camada de areia fina que cobria os mosaicos. Efectuou-se também a consolidação e reconstituição de algumas estruturas com uma argamassa à base de cal hidráulica e saibro. Foi aplicado um biocida (Dipcid da CIN) nas áreas mais elevadas que já não estavam protegidas e apresentavam microorganismos (AMDDS). Ainda durante o ano de 1997 começaram os preparativos do espaço dos mosaicos para ser musealizado. Durante o Inverno e quase diariamente, verificava-se a existência de inundações e infiltrações, a partir do tecto e junto às paredes do piso. Em 2003/2004, foi construída uma galeria para resolver esta situação e drenar o espaço envolvente ao mosaico, mas não ficou bem executada.

Desde 1998, que se verificam infestações, que se desenvolvem devido à entrada de luz pela clarabóia e pela humidade geral existente nas paredes e sob a área do mosaico. De 1999 a 2004 foram efectuadas várias limpezas com vapor de água e esponja e aplicado o biocida "Dipcid" da Tintas CIN em toda a área de ruínas, que não estavam protegidas da entrada de luz, para tentar eliminar microrganismos. Concluiu-se que este processo de limpeza e o biocida aplicado não estavam a resolver a eliminação das áreas verdes. Verificou-se ainda que a entrada de luz pelas clarabóias, conjuntamente com a humidade existente, tornava muito difícil o combate aos musgos (Figura 1).

No sentido de procurar diminuir as entradas de luz natural, e assim reduzir o aparecimento de fungos e algas, foi pedida a aquisição de uma película de raios ultravioletas ao Instituto Português de Museus. Como a resposta tardou e numa tentativa de evitar a propagação de microrganismos nas áreas limpas, colocou-se manga plástica preta. Como não se conseguia eliminar a infestação de microorganismos com o "Dipcid”, especialmente nas áreas mais próximas da entrada de luz (clarabóia), decidiu-se aplicar outro biocida, o "25X" e finalmente foi feita uma aplicação do biocida Preventol R8o, mas todas as diligências efectuadas até agora não resultaram (Figura 2).

Perante as situações apresentadas, podemos apontar algumas soluções: procurar diminuir a entrada de luz natural, proceder à drenagem das estruturas e aplicar biocidas adequados para eliminação dos fungos. Mas serão necessárias verbas para proceder a mais estudos microbiológicos e resolver de vez a drenagem desta área com a construção de uma nova galeria que 
envolva toda a caixa, onde está inserida esta Domus. Mas nesta época de escassos recursos, com um orçamento mínimo para a Cultura, constitui um grande desafio encontrar financiamento, que permita a realização destes empreendimentos, que só poderão avançar através de patrocínios ou de intercâmbios entre universidades, ou no âmbito de mestrados e doutoramentos. Entretanto, pode ser feito um ensaio, utilizando lâmpadas ultravioletas, que poderão ficar activas durante a noite, para minimizar o crescimento de fungos neste ambiente húmido.

A estes mosaicos, decorados com temas que se verificam desde época recuada a época tardia, foi atribuída uma datação alto-imperial tendo em conta a análise das estruturas da casa a que pertenciam, a perfeição da canalização em granito que passa sob os painéis, o rigor da execução dos temas decorativos e a dimensão e densidade das tesselas. Tendo Bracara Augusta sido objecto de um programa construtivo realizado entre o último quartel do século I e os inícios do século II d. C., os mosaicos poderão corresponder a estruturas dessa época.

B - Os mosaicos da Domus da Sé Velha - Rua D. Afonso Henriques, № 1, Bracara Augusta/Eixo Interior

Em 1998, devido a uma proposta de remodelação do edifício da antiga "Escola Velha da Sé", procedeu-se a uma intervenção arqueológica que foi realizada pelo Gabinete de Arqueologia da Câmara Municipal de Braga, dirigida pelo Dr. Armandino Cunha, cujos trabalhos decorreram, em diferentes fases, até 2003 (Figura 3).

A área intervencionada, na cave do edifício da Escola Velha da Sé, ocupa uma superfície total de 720 $\mathrm{m}^{2}$, onde foi reconhecida a parte sul de uma habitação romana, na qual se destacam os vestígios de um hipocausto e de pavimentos revestidos com material laterício e mosaicos. Parte do mosaico encontra-se in situ, onde tem sido consolidado (CMRCB, mosaico 15, pp. 84-88). Em Março de 200o, cinco fragmentos muito frágeis foram levantados e consolidados com Plexigum N8o e aplicação de tela. Estes fragmentos deram entrada na reserva do MDDS. Foram individualizadas três fases construtivas para esta habitação, tendo por base a estratigrafia e os materiais arqueológicos analisados. A primeira fase pode ser datada do século I. A segunda fase corresponde a uma remodelação significativa da habitação, que pode ser datada de entre os finais do século III e os inícios do século IV, tendo em conta o contexto arqueológico e a análise estilística dos mosaicos. A remodelação da domus que define esta segunda fase de ocupação caracterizou-se pela construção de um balneário, na área sudoeste do edifício. A edificação do complexo de banhos sacrificou a zona da casa anteriormente ocupada por um possível peristylium. Relacionado com esta reforma está um pavimento em mosaico que recobria um extenso corredor e que permitia aceder à nova área da habitação, possibilitando a articulação do espaço de banhos com outros compartimentos da casa (Magalhães, 2010, pp. 50-51).

Este mosaico de tesselas bicromas (calcário branco e preto) apresenta um padrão ortogonal de círculos e quadrados no vértice determinando bobinas. Para o esquema decorativo deste mosaico de pavimento, encontraram-se paralelos em mosaicos da Hispania, incluindo a Gallaecia, e do Norte de África, datados dos séculos II-III, III, III-IV e século IV. Quanto à decoração realizada no interior dos círculos, ela parece ser uma adaptação de ressaltos desiguais ao espaço circular ou de ressaltos arredondados. Nos mosaicos do Conuentus Bracaraugustanus, muitas das figuras geométricas de vários esquemas compositivos são decoradas interiormente com ressaltos desiguais, mesmo no interior de um círculo, como se verifica num mosaico da Villa de Tralhariz (CMR$C B$, mosaico 93) que poderá ser um pouco posterior ao desta domus de Braga. A utilização de ressaltos ao jeito de "corola" pode dever-se à inabilidade do artífice mosaísta na cópia de modelos, mas também pode revelar certa capacidade criativa ao realizar este motivo para o qual não se encontraram paralelos.

Para além deste mosaico foram identificados nas salas limítrofes outros pequenos fragmentos com tesselas de várias cores, mas devido à sua fragmentação não foi possível caracterizá-los. (Magalhães, 2010, pp. 57). Na parte Oeste do edifício, no prolongamento do espaço musealizado, foi aberto um restaurante com entrada pelo Campo das Carvalheiras, no ${ }_{13}$, mas que mantem uma porta que dá acesso ao espaço musealizado. Muitas vezes durante o período das refeições esta porta é aberta e os utentes do restaurante podem circular livremente pelo espaço musealizado pondo em risco as estruturas das habitações romanas.

C - Mosaico da Domus de Sendim, Felgueiras, Porto /Eixo Interior

$\mathrm{Na}$ estação arqueológica de Sendim, Felgueiras, Por- 
to, os trabalhos de escavação dirigidos por Marcelo Mendes Pinto puseram a descoberto algumas das estruturas da pars urbana de uma Villa, com pavimentos musivos. Um dos mosaicos que subsiste, muito deteriorado, corresponde ao pavimento de um cubiculum, tendo sido datado de entre finais do século III e finais do século IV. Esta datação teve por base o contexto arqueológico que aponta para uma significativa renovação da pars urbana desta Villa em finais do século III, bem como a análise estilístico-comparativa dos temas decorativos usados. $\mathrm{O}$ tapete principal e maior apresenta uma composição centrada por um octógono com uma estrela de 8 losangos, que encontra paralelos em mosaicos do território português como nos das Villae de Cerro da Vila e Milreu e de Conímbriga ("Casa dos esqueletos”), todos datados dos séculos III-IV, e do Norte de África, salientando-se um mosaico de Thysdrus, das primeiras décadas do século III. O motivo da "estrela de 8 losangos" em diferentes composições de superfície é muito frequente na arte do mosaico do mundo romano.

A faixa de ligação ao tapete menor que corresponde à zona do lectus, elevada por um pequeno degrau, apresenta duas fiadas de moinhos de peltas à volta de nó-de-Salomão, decoração também ocorrente em outros mosaicos tardios hispânicos, nomeadamente do território português, igualmente datados dos séculos III-IV. (CMRCBA, mosaico 72, pp.183-193).

O mosaico mantém-se in situ e apresenta-se muito danificado. Foi construída sobre toda a área da estação arqueológica uma cobertura de madeira, que protege todas as estruturas.

\section{D - O mosaico da casa do Infante, Porto/ Eixo do Douro}

No decurso da intervenção arqueológica realizada na Casa do Infante, na zona ribeirinha da cidade do Porto, identificaram-se dois pavimentos de mosaico. Os trabalhos arqueológicos foram motivados pelo projecto de remodelação e ampliação do edifício onde se encontra instalado o Arquivo Histórico Municipal cuja matriz surge definida no século XIV com a construção da Alfândega régia e da Casa da Moeda. Subjacente a estas construções foi escavada uma sequência de ocupação alto-medieval e tardo-romana na qual se integram os dois pavimentos de mosaico, correspondentes a dois compartimentos da habitação tardo-romana. Para a decoração que apresentam foram encontrados paralelos em mosai- cos hispânicos, sobretudo do território português, enquadráveis nos séculos III e IV (CMRCB, Mosai$\cos 82$ e 83, pp. 209-220).

O tipo de solo caracterizado por um elevado teor de humidade e $\mathrm{pH}$ ácido condicionou a preservação dos dois pavimentos de mosaico que apresentavam um avançado estado de degradação física e química com perda da maioria das tesselas.

Dado o acentuado estado de degradação dos pavimentos o projecto de exposição optou por fazer substituir a sua exibição directa por uma réplica.

\subsection{MOSAICOS CONSERVADOS IN SITU NÃO MUSEALIZADOS.}

A - Pavimento misto, em opus sectile e opus tessellatum, Bracara Augusta/Eixo Interior

Na área do actual jardim do Museu D. Diogo de Sousa (BA-Cavalariças/BRA88CVL, zona X126Y173-sond. 079), foram descobertas estruturas que apresentavam um pavimento misto, em opus sectile e opus tessellatum, que depois de estudado, desenhado e fotografado, permaneceu in situ, coberto com tela sintética e areia. (CMRCB, mosaico 2, pp.55-58). Foram retiradas algumas lajes de granito que se encontram na reserva do MDDS.

Este tipo de pavimento em que se usam os dois opera constitui um unicum no conjunto dos mosaicos do Conuentus Bracaraugustanus. As lajes, hexagonais e quadradas, dispor-se-iam regularmente ao longo da superfície do pavimento, sendo cada quadrado rodeado por quatro hexágonos. As tesselas, policromas, que subsistiram entre as lajes, desenhariam uma trança de dois cordões (Abraços, 2016, p. 320, Figs. 5 e 8), o que leva a supor o seu envolvimento por este tema, produzindo o conjunto um belo efeito decorativo. Atendendo a que este pavimento foi encontrado a uma cota superior relativamente à domus da cripta do MDDS, numa área da cidade que não terá sido abandonada, embora tenha visto alterado o seu protagonismo no século $\mathrm{V}$, em detrimento do novo centro urbano deslocado para nordeste, e sabendo-se que os pavimentos mistos foram muito usados em época bizantina, considerou-se possível atribuir-lhe uma datação, ainda que interrogada, nos séculos V-VI.

\section{B - Mosaico da Casa da Roda}

Na Rua de S. João, em Braga (BRAgo/92 CRO) foi realizada uma escavação, onde foi descoberto um 
mosaico com suporte original (CMRCB, mosaico 34, pp.112-123). Após consolidação, in situ, pela equipa técnica do MDDS, o mosaico foi tapado com tela sintética e areia. O mosaico in situ encontra-se enterrado sem que exista, no referido edifício, qualquer referência ao local preciso do achado, ou alguma fotografia ilustrativa daquele que será um dos mais ricos mosaicos que até ao presente nos chegou, provenientes da capital da Gallaecia (Figura 4):

É um mosaico policromo de tesselas em calcário branco, preto, vermelho e amarelo que, no limitado espaço posto a descoberto (cerca de 2,30 $\mathrm{m} \mathrm{x} \mathrm{1,50} \mathrm{m),}$ se organizam em quatro diferentes temas decorativos: linha descontínua de florzinhas em cruz; linha de peltas alternadamente invertidas com folhas cordiformes no vértice mediano; onda policroma e linha de sólidos. Ainda que todos os temas encontrem paralelos em mosaicos hispânicos, norte-africanos e do Oriente mediterrânico, no que respeita à linha de sólidos será de salientar que este tema está pouco documentado nos mosaicos do actual território português, conforme referimos no $C M R C B$ (pp. 118-119). A análise estilistico-comparativa dos diferentes temas ocorrentes no mosaico da Casa da Roda e as informações sobre a arqueologia de Bracara Augusta que sofreu um significativo desenvolvimento construtivo após a sua passagem a capital da Gallaecia levaram a datar este mosaico de entre os séculos III e IV.

\section{C - Mosaicos de Vizela/ Eixo Interior \\ (CMRCB, mosaico 71 A e B, pp. 180-182)}

$\mathrm{Na}$ actual Praça da República, foram referenciadas desde o século XIX, evidências de estruturas termais romanas, onde terá sido posto a descoberto um mosaico romano do qual ficaram desenhos no Museu da Sociedade Martins Sarmento (CMRCB, mosaico $71 \mathrm{~A}$ ), bem assim como outros vestígios dispersos pelo complexo balnear.

Em 1898, e por ocasião de novas obras, foi encontrado um outro mosaico integrado numa estrutura de banhos, a qual posteriormente se enterrou. Durante uma intervenção de emergência realizada pelo arqueólogo Francisco Queiroga (Queiroga 2013, pp. 181-201), em 1996/97 foi descoberto junto ao tanque termal um outro mosaico (CMRCB, mosaico 7 B). Todo este legado se encontra ainda in situ e coberto.

Os mosaicos provenientes do complexo termal apresentam decoração geométrica que se enquadra nas características estilísticas de outros mosaicos do
Conuentus Bracaraugustanus e de outras regiões administrativas romanas, nomeadamente da Gallaecia. (Figura 5)

Um dos mosaicos é composto por quadrados e losangos adjacentes, encaixados, todos delineados no interior por filetes denticulados, sendo os losangos ainda sublinhados interiormente por ressaltos desiguais. Os quadrados levam ao centro nó de Salomão (um deles de voltas rectilíneas), moinho de velas e florzinha com borlas. A composição de superfície que no território português aparece, por exemplo, em um mosaico de Conímbriga da "Casa da cruz suástica”, datado da $2^{\mathrm{a}}$ metade do século III (Correia, 2003, p. 25; Oliveira, 2005, p. 40, mosaico 24.1), é um tipo de composição geométrica que surge também em Lugo e La Cigarrosa (Orense), na Gallaecia (Torres Carro, 2015ª, p. 215). No mosaico de Lugo, no Museu Provincial desta cidade, o esquema compositivo é usado em uma larga faixa que enquadra as figurações de Dédalo e Pasífae (Regueras Grande, 2015, p. 283; Irastorza \& Carnero Vásquez, 2015, p. 255, Fig. 5). O outro mosaico aparenta uma composição em quadrados, sendo visível em um deles o mesmo tipo de filete denticulado no seu interior. Por comparações estilísticas com outros mosaicos, os mosaicos de Vizela poderão datar do século IV.

\section{D - Freixo, Marco de Canaveses/Eixo do Douro} Em Marco de Canaveses, a Igreja de Santa Maria do Freixo foi objecto de escavação arqueológica, iniciada em 2001. No subsolo da actual igreja foi detectada uma construção de consideráveis dimensões com pavimentos revestidos a mosaico (CMRCB, mosaico 86, pp. 222-230). Segundo António Manuel de Carvalho Lima este mosaico apresenta uma datação não anterior a meados do V e em uso ainda no VI. Os mosaicos mantêm-se in situ, excepto um pequeno fragmento que foi removido e exposto no Centro Interpretativo de Tongobriga. Actualmente nada se encontra visível. Os mosaicos que revestiam os compartimentos A e B preservam-se sob o soalho da igreja paroquial.

\subsection{MOSAICOS LEVANTADOS E CONSERVADOS NAS RESERVAS DOS MUSEUS}

\author{
A - Rua 25 Abril, Quinta do Fujacal \\ Em 2001, na estação Arqueológica da Rua 25 Abril, \\ Quinta do Fujacal (escavação: BRA20oıBMIS, zona
}


B20, n.․ complexo 9, n.. campo 1/Unidade estratigráfica 031 - Enchimento da vala de saque UE 030). Fragmento de mosaico com suporte original, sobreposto a outro fragmento de mosaico (CMRCB, mosaico 7, pp.66-67). Deu entrada em 20.02.2001, no MDDS para tratamento de conservação.

O fragmento de mosaico bicromo (branco e preto), de tesselas calcárias, no qual se desenha um triângulo de base côncava, centrado por uma cruzeta de quatro tesselas, foi encontrado num contexto arqueológico datável do século I, época Flaviana. A perfeição de execução do tessellatum, a densidade das tesselas, 145/ dm2, e o contexto arqueológico do achado levaram a atribuir a sua realização à época Flaviana.

B - Estruturas de tanques revestidos a mosaico/ Cardoso da Saudade, Largo de S. Paulo, Bracara Augusta/Eixo Interior

$\mathrm{Na}$ estação Arqueológica Cardoso da Saudade, no Largo de S. Paulo, foram postas a descoberto estruturas de três tanques (CMRCB, Mosaicos 11 a 13, pp. 73-80). Um foi escavado em 1968, mas apenas se conservava o fundo, revestido a mosaico já muito danificado, e duas paredes. Este, em data desconhecida, terá sido incorporado noutro tanque de maiores dimensões. Esta remodelação pode ter estado na origem dos maiores danos do mosaico. Actualmente existem apenas fragmentos com suporte original no MDDS e outros continuam in situ. Ainda no mesmo ano foi posto a descoberto outro tanque de onde foi retirado um fragmento decorado com cabeça incompleta de um peixe, pertença da colecção do MDDS. Em 1993, foram descobertos grandes fragmentos de mosaico que revestiam as paredes e o fundo de um tanque com degraus, decorados com florzinhas em cruz de tesselas pretas sobre fundo de tesselas brancas. O mosaico está em desagregação e encontra-se muito fragmentado. Quando do levantamento do mosaico procedeu-se à limpeza da sua superfície e foi feita a sua consolidação com Plextol B500; colagem de gaze sobre todo o mosaico utilizando Plextol B50o; colagem de uma tela de pano-cru sobre a gaze; construção de contramoldes em poliuretano expandido. Encontra-se em completa desagregação.

\section{C-Mosaicos da Rua D. Afonso Henriques núme- ros 20-28, Bracara Augusta/Eixo Interior}

(CMRCB, mosaicos 17 a 30, pp. 91-106)

Outro conjunto de mosaicos foi descoberto nas sondagens arqueológicas que tiveram lugar no edifício da Rua D. Afonso Henriques números 20-28, que depois das escavações foi restaurado e reconvertido em Hotel, em 2017. Nesta escavação foram recolhidos mais de quatrocentos fragmentos, depositados como entulhos de remodelações, como provam as dez fases construtivas apresentadas no relatório de escavação (Trabalhos Arqueológicos da U.A.U.M./ Memórias, 25, 2012).

Alguns dos fragmentos apresentam medalhões circulares, na sua maioria delimitados por faixas de tesselas brancas e trança de dois cordões e, no interior, florões e vasos desenhados sobre fundo de tesselas pretas. Estes fragmentos, com idêntica técnica de execução, semelhante densidade das tesselas e o mesmo tipo de argamassas do tardoz, parecem fazer parte de um mesmo pavimento musivo que poderia apresentar uma composição de superfície de círculos tangentes, determinando quadrados côncavos, sendo visível, em um dos fragmentos, um segmento de círculo determinando um dos lados do quadrado. O tipo de florão representado encontra paralelos em florões com folhas fuseladas e estames, só com estames, ou com a junção de vários tipos de folhas, em mosaicos de território português como em Conímbriga ("Casa da cruz suástica" e "Casa dos esqueletos”), Torres Novas (Villa Cardílio), Pisões, Cerro da Vila, Abicada e, particularmente, no mosaico do Oceano de Faro (Wrench, 2005, pp. 33-48, Est. 1-5), podendo todos eles ser integrados nos séculos III e IV. Em mosaicos norte-africanos, datados dos séculos III-IV, o estilo de florões aproxima-se ao dos ocorrentes no Mosaico do Oceano de Faro, sendo o florão XIIb aí desenhado bastante semelhante aos do mosaico de Braga. Relativamente aos círculos, emoldurados por faixas brancas e trança de dois cordões, foram encontradas semelhanças com os desenhados em pavimentos da Domus Oceani de Lugo (sala que antecede o oecus e uma das alas do pátio porticado), aparecendo o círculo com trança de dois cordões bastante documentado na musivária tardia hispânica da zona centro (González Fernández, 2005, Figs. 58, 65, 96 e p. 91). O conjunto dos mosaicos desta casa situa-se cronologicamente entre finais do século III e princípios do século IV (González Fernández, 2015, p. 225). Tanto os mosaicos da sala que antecede o oecus como o do oecus terão sido realizados por oficina de Lugo que usou procedimentos de execução idênticos aos usados por oficinas norte-africanas, concretamente de Cherchel, Thuburbo Majus e Timgad (Torres Carro, 2015 b p. 336). Refira- 
-se também que no repertório compositivo dos mosaicos galegos, se emprega com frequência a figura do quadrado e do círculo em diversas combinações (Torres Carro, 2015' , p. 214).

Quanto aos vasos esquemáticos e bastante atípicos, de onde saem grossas volutas brancas, poder-se-á supor para eles uma realização mais tardia do que a dos florões. A análise estilística, as técnicas de execução e o contexto arqueológico levaram a propor os séculos III-IV para a realização deste mosaico que terá sido todo fragmentado.

\section{D-Mosaicos da Rua D. Afonso Henriques nos 42- 56, Bracara Augusta/Eixo Interior}

Outro grupo de fragmentos de mosaico foi descoberto na Rua D. Afonso Henriques n⿳s ${ }^{0} 2-56$. Os trabalhos arqueológicos foram executados nos anos de 1998 e 2002. A campanha de 1998 decorreu entre 18 de Maio e 10 de Novembro, tendo então sido abertas seis sondagens de $4 \times 4 \mathrm{~m}$, tendo em vista proceder a uma avaliação preliminar do potencial estratigráfico e patrimonial do logradouro. Tendo-se verificado que as estruturas romanas se encontravam a cerca de $2,5 \mathrm{~m}$ da superfície do solo atual e dada a dificuldade de remoção de terras do interior do quarteirão, os trabalhos arqueológicos foram interrompidos em Novembro de 1998 e retomados em 2002. Esta segunda fase dos trabalhos compreendeu a realização de uma escavação em área, com cerca de $307 \mathrm{~m}^{2}$. (Trabalhos Arqueológicos da U.A.U.M. / MEMÓRIAS, 48, 2014, 10-12). Foram descobertos fragmentos de mosaico, que fariam parte de um balneário que teve uma remodelação num período que os arqueólogos admitem situar-se entre finais do século III/ inícios do IV, quando se registaram importantes transformações no balneário, que modificaram a funcionalidade de alguns espaços. Um dos aspetos mais marcantes da remodelação operada nesse período associa-se ao aumento dos espaços frios do balneário e a uma diminuição de áreas quentes (Trabalhos Arqueológicos da U.A.U.M. / MEMÓRIAS, 48, 2014, 78). Sobre os níveis de enchimento do hipocausto foi assente um solo de opus signinum, que revelou decoração com mosaico, infelizmente muito destruído, cuja cota tinha 192,20m. A poente da nova sala fria deveria existir um outro espaço frio, que recebeu um pavimento de opus signinum, decorado com mosaico, registado numa área muito circunscrita das sondagens (Trabalhos Arqueológicos da U.A.U.M./ MEMÓRIAS, 48, 2014,
79). Admitindo que esta sala teria funcionado no período anterior como tepidarium, presume-se que o seu hipocausto tenha sido entulhado para permitir o assentamento do pavimento com decoração musiva (CMRCB, mosaicos 31 a 33, pp.107-111).

Todo o espólio deu entrada no MDDS foi lavado, marcado, inventariado e devidamente acondicionado, tendo o seu tratamento sido realizado por alunos de Mestrado de Arqueologia da Universidade do Minho, no ano académico de 2011-2012 (Trabalhos Arqueológicos da U.A.U.M. / MEMÓRIAS, 48, 2014) em colaboração com o pessoal do referido Museu. Os fragmentos de mosaico apresentam suporte original, mas em desagregação, foram removidos limpos e consolidados com plexigum N8o e acetona. Os fragmentos de mosaico nos 31 e 32 encontram-se na reserva do MDDS. O mosaico 33 continua in situ. Foi consolidado com Plextol B500 e água e depois coberto.

\section{E-Mosaicos provenientes do quintal de Fernando Castiço, Braga/ Eixo Interior}

O Museu Arqueológico da Sociedade Martins Sarmento (MASMS) guarda um conjunto de vinte e dois fragmentos de mosaicos, provenientes de Braga. Os fragmentos, todos em opus tessellatum e com suporte original, não apresentam restauros antigos, constituindo um material significativo quanto às temáticas decorativas, técnica de execução e de assentamento (CMRCB, mosaicos 40 a 6o, pp. 131-161). Em 2014, quando visitámos o Museu para fotografar os mosaicos, estes já tinham sido inventariados, limpos e consolidados.

\section{F-Mosaicos de Dume, Braga/Eixo Interior (CMRCB, mosaicos 61 a 68, pp.16o-177)}

Em 1987, foram realizadas escavações de emergência, em Dume, junto à Igreja Paroquial e na Capela de Nossa Senhora do Rosário, onde se pôs a descoberto as estruturas da antiga Igreja e Mosteiro de Dume, datáveis do séc. VI d.C. (SMD87, zona A72, n.. campo 75, fase II). Os mosaicos encontrados no espaço da basílica paleocristã e na necrópole alto-medieval foram todos reaproveitados em épocas posteriores e podem ter estado associados, quer ao edifício balnear datável dos séculos III-IV, anexo à Villa romana, quer à basílica paleocristã. A decoração que apresentam tem paralelos em outros mosaicos, cujo espectro cronológico igualmente varia entre os séculos III e VI. Dois destes fragmentos (Mosaicos 
61 e 62) apareceram num degrau de acesso exterior à abside sul da cabeceira trilobada, orientada, da basílica do século VI, acesso correspondente a uma remodelação no século X.

Um dos fragmentos (Mosaico 62) é constituído por tesselas de calcário preto, branco e rosa e por tesselas cor de tijolo, com a densidade de 110/dm2. É decorado por círculos concêntricos e um meandro fraccionado (?), levando o círculo central uma florzinha em cruz, marcada por tesselas pretas, envolvida por uma corola policroma. O motivo aparenta uma flor de 4 pétalas bilobadas, organizadas nos quadrantes definidos pela cruzeta de tesselas pretas. Este tipo de flor é semelhante ao ocorrente em mosaicos da Villa de Almoçageme, Sintra, nomeadamente em um dos painéis do triclinium, datado da segunda metade do século III (Caetano, 2012, pp. 877-881 e p.887, Fig. 5), ou ao que ocorre na abside de uma sala da parte sul da Villa de Santiago da Guarda, Ansião, Leiria, datável dos séculos IV-V. Trata-se de um motivo que surge em alguns mosaicos africanos desde o século II, adquirindo grande popularidade na musivária da zona oriental do Império, especialmente a partir do século $\mathrm{V}$, tanto em contextos religiosos cristãos como domésticos.

Os mosaicos provenientes dos sítios arqueológicos de Dume foram tratados pelos técnicos de restauro do MDDS, encontrando-se actualmente no espaço musealizado da Basílica paleocristã.

\section{G-Mosaicos da Villa de Granjinha, Chaves/Eixo Interior \\ (CMRCB, mosaico 75, pp. 197-20o)}

Os fragmentos de mosaico, provenientes desta $V i$ lla, encontram-se expostos no Museu da Região Flaviense, na cidade de Chaves. Os cinco pequenos fragmentos são constituídos por tesselas de calcário branco, preto e vermelho, apresentando um deles tesselas de cor verde-água. Junto à zona onde haviam sido encontradas tessellae, foi detectado um impluuium e recolhido um espólio que não incluía tesselas, mas outros materiais datáveis de entre os séculos II e III. Tanto a técnica de execução como o espólio arqueológico recolhido na área levaram a atribuir a estes fragmentos uma datação enquadrada nos séculos II-III.

H - Fontão de Antela, Lavra, Matosinhos/Eixo Atlântico

(CMRCB, Mosaicos 76 a 81, pp. 201-204)
Esta estação de Fontão de Antela não foi ainda objecto de escavações sistemáticas, mas têm aparecido pontualmente diversos elementos que nos indicam ter existido aqui uma estação arqueológica relativamente importante, nomeadamente fragmentos de mosaicos. Estas estruturas parecem datar duma época tardia da romanização (séculos III-IV) (Figura 6).

I - Quinta da Ribeira, Tralhariz, Carrazeda de Ansiães/Eixo do Douro

(CMRCB, mosaico 93, pp. 240-242).

Este arqueossítio ficou particularmente famoso devido ao aparecimento de mosaicos policromos com decoração geométrica. Com esta proveniência existe um pequeno fragmento de mosaico incaracterístico no Museu Nacional de Arqueologia (MNA 16761); outros continuam in situ; outros desapareceram. Segundo os relatos da época, mais tarde compilados por Fernando Russel Cortez (Cortez, 1946, pp. 3045 ), os mosaicos surgiram em quatro compartimentos rectangulares que estruturavam um edifício. - (Portal do Arqueólogo, DGPC-CNS.2188). Aquando do achado, o pavimento melhor conservado perdera o emblema central. Pelo desenho que lhe corresponderá, o quadro central estaria inserido numa composição de meandros de suásticas em trança de dois cordões e 4 quadrados angulares. O emblema central é enquadrado por uma faixa decorada por guilhoché e o quadrado angular é demarcado exteriormente por trança de dois cordões. Um dos quadrados nele encaixado é demarcado por ressaltos desiguais. Exteriormente a esta composição, é visível uma larga faixa decorada por uma linha de círculos e quadrados sobre o vértice, decoração que é geralmente usada em composições de superfície e nas quais os círculos e os quadrados determinam rectângulos de lados curvos ou bobinas. O círculo visível é decorado interiormente por uma faixa de ressaltos desiguais e os quadrados por meandro fraccionado. A composição em que se inseria o emblema central encontra paralelos no "mosaico dos cavalos" de Torre de Palma, datado de finais do século III, inícios do século IV, em mosaicos de Quintana del Marco (León) e de Camarzana de Tera (Zamora), datáveis dos séculos IV-V. A decoração da faixa exterior de quadrados e círculos assemelha-se à do "mosaico de Hilas e as Ninfas” de Quintana del Marco (León) e surge, como composição de superfície, em vários mosaicos tardios do território português, como no mosaico da Coriscada, Meda, Foz Côa, a sul de Tra- 
lhariz, ou no mosaico de Braga da Rua D. Afonso Henriques, ํㅡ 1 (Mosaico 15). Atendendo às suas características estilísticas, o mosaico de Tralhariz foi datado dos séculos IV-V.

\section{CONSIDERAÇÕES FINAIS}

Os mosaicos deste Conuentus foram descobertos a partir do final do século XIX e encontrados, quase na sua totalidade, em estruturas arquitectónicas. $\mathrm{Na}$ área de Bracara Augusta o conhecimento dos sítios arqueológicos deve-se ao trabalho desenvolvido desde a década de setenta, quando foi criado o Campo Arqueológico de Braga, encarregado de proceder a salvamentos na área urbana e de verificar a extensão da cidade romana. Excluindo as intervenções arqueológicas de salvamento de emergência, tem sido prática das diferentes equipas conservar in situ as estruturas e os mosaicos descobertos durante as escavações. Quando não estão reunidas as condições para a sua manutenção in situ, os mosaicos são levantados, limpos e consolidados e ingressam nas reservas dos museus.

Relativamente às cronologias propostas para os mosaicos deste Conuentus, a sua maioria localiza-se nos séculos III-IV, época em que Bracara Augusta adquirira o estatuto de capital provincial, tendo sido criada a Gallaecia e acrescentada às demais Províncias romanas da Hispania.

Quanto à decoração dos mosaicos aqui apresentados, verifica-se que ela diz respeito a um repertório generalizado na arte do mosaico romano, desde época recuada a época tardia, com paralelos encontrados em mosaicos da área do próprio Conuentus, mas também de outras áreas administrativas romanas, tanto do território português como do espanhol, das províncias romanas do Ocidente, incluindo o Norte de África, e do Oriente mediterrânico.

Será de atentar que em alguns dos motivos decorativos dos mosaicos do Conuentus Bracaraugustanus são evidentes imperfeições na execução dos mesmos, o que aponta para o trabalho de artífices locais ou regionais. Alguns dos desvios aos modelos podem ser também considerados como certa capacidade criativa da parte desses artífices. Outro aspecto regional destes mosaicos estará patente na pouca variedade da paleta cromática das tesselas calcárias, material pouco abundante numa região por excelência granítica, preferindo-se para o vermelho a cerâmica cor de tijolo, usando-se os calcários pre- to, branco e cinzento e, pontualmente, o vermelho, rosa, amarelo e verde-água. Os exemplos de Braga referentes aos pavimentos de uma domus, expostos na cripta do MDDS, nos quais se usaram tesselas de granito róseo e ao pavimento tardio da mesma cidade, em opus tessellatum e opus sectile, composto por lajes de granito, revelam como deste material se tirou partido, numa região em que ele é abundante.

\section{BIBLIOGRAFIA}

ABRAÇOS, Maria de Fátima (coordenação de) (2019), LIMA, António; MOURÃO, Cátia; ABRAÇOS, Fátima; LIMÃO, Filomena; WRENCH, Licínia; PINTO, Marcelo Mendes; GOMES, Paulo Dórdio; LOPES, Rui, O Corpus dos Mosaicos Romanos do Conuentus Bracaraugustanus. Centro de Estudos Históricos, Universidade NOVA de Lisboa.

ABRAÇOS, Maria de Fátima (2016) - Os Mosaicos Romanos de Bracara Augusta. Novos Achados. In NEIRA JIMÉNEZ, Luz, ed. Estudios sobre mosaicos antiguos y medievales, Actas del XIII Congreso AIEMA Madrid, 14-18 septiembre de 2015. Roma: «L'ERMA» di Bretschneider, pp. 315-322.

CAETANO, Maria Teresa (2012) - Mosaicos da Finisterra Ocidental - a Villa de Santo André de Almoçageme. In X Colóquio do Mosaico Greco-Romano. O Mosaico Romano nos Centros e nas Periferias. Originalidades, influências e identidades. Conímbriga: (2005) 2012, pp. 873-887.

CORREIA, Virgílio Hipólito (2003) - Conimbriga. Guia das Ruínas. Instituto Português de Museus.

GONZÁLEZ FERNÁNDEZ, Enrique (2005) - DOMVS OCEANI. Aproximación á arquitectura doméstica de Lucus Augusti. Traballos de Arqueoloxía 2, Concello de Lugo, Servizo de Arqueoloxía - Concellería de Urbanismo.

GONZÁLEZ FERNÁNDEZ, Enrique (2015) - Los Mosaicos de la Domus Oceani (Lugo). In PESSOA, Miguel Coord. Actas do Encontro Portugal - Galiza. Mosaicos Romanos Fragmentos de Cultura nas Proximidades do Atlântico (6 e 7 de Julho de 2013), Rabaçal, Braga e Lugo. APECMA/AIEMA, pp. 225-247.

IRASTORZA, Enrique; CARNERO VÁZQUEZ, Ofelia (2015) - Mostras Musivarias Romanas no Museo Provincial de Lugo. Algunhas Observacións ao Mosaico de Dédalo e Pasifae e Xeométrico. In Pessoa, Miguel Coord. - Actas do Encontro Portugal-Galiza. Mosaicos Romanos-Fragmentos de Cultura nas Proximidades do Atlântico (6 e7 de Julho de 2013), Rabaçal, Braga e Lugo. APECMA/AIEMA, pp. 248-265.

MAGAlHÃES, Fernanda Eugénia Puga (2010) - Arquitectura doméstica em Bracara Augusta. Tese de Mestrado de Arqueologia. Universidade do Minho, Instituto de Ciências Sociais.

OLIVEIRA, Cristina (2005) - Mosaicos de Conímbriga. X Colóquio Internacional AIEMA. Conímbriga: Instituto Português de Museus-Museu Monográfico de Conímbriga. 
REGUERAS GRANDE, Fernando (2015) - Mosaicos Romanos del Conventus Asturum. Estado de la Cuestion y Encrucijada Patrimonial. In PESSOA, Miguel, Coord. - Actas do Encontro Portugal - Galiza. Mosaicos Romanos - Fragmentos de Cultura nas Proximidades do Atlântico (6 e 7 de Julho de 2013), Rabaçal, Braga e Lugo. APECMA/AIEMA, pp. 279-304.

TORRES CARRO, Mercedes (2015a) - Mosaicos Romanos da Galicia. In PESSOA, Miguel, Coord. - Actas do Encontro Portugal - Galiza. Mosaicos Romanos - Fragmentos de Cultura nas Proximidades do Atlântico (6 e 7 de Julho de 2013), Rabaçal, Braga e Lugo. APECMA/AIEMA, pp. 196-224.

TORRES CARRO, Mercedes (2015b) - A propósito del análises de la estrutura geométrica de la decoracion del mosaico de la antesala del Oecus de la "Domus Oceani” de Lugo. In PESSOA, Miguel, Coord. - Actas do Encontro Portugal - Galiza. Mosaicos Romanos - Fragmentos de Cultura nas Proximidades do Atlântico (6 e 7 de Julho de 2013), Rabaçal, Braga e Lugo. APECMA/AIEMA, pp. 336-338.

WRENCH, Licínia N. C. (2005) - Decoração vegetalista nos mosaicos portugueses Lisboa: Ed. Colibri/IHA.

\section{ABREVIATURAS}

AMDDS - Arquivo do Museu D. Diogo de Sousa.

APECMA - Associação Portuguesa para o Estudo da Conservação do Mosaico Antigo.

CMRCB - O Corpus dos Mosaicos Romanos do Conuentus Bracaraugustanus.

MDDS - Museu D. Diogo de Sousa.

MASMS - Museu Arqueológico da Sociedade Martins Sarmento.

UAUM - Unidade de Arqueologia da Universidade do Minho

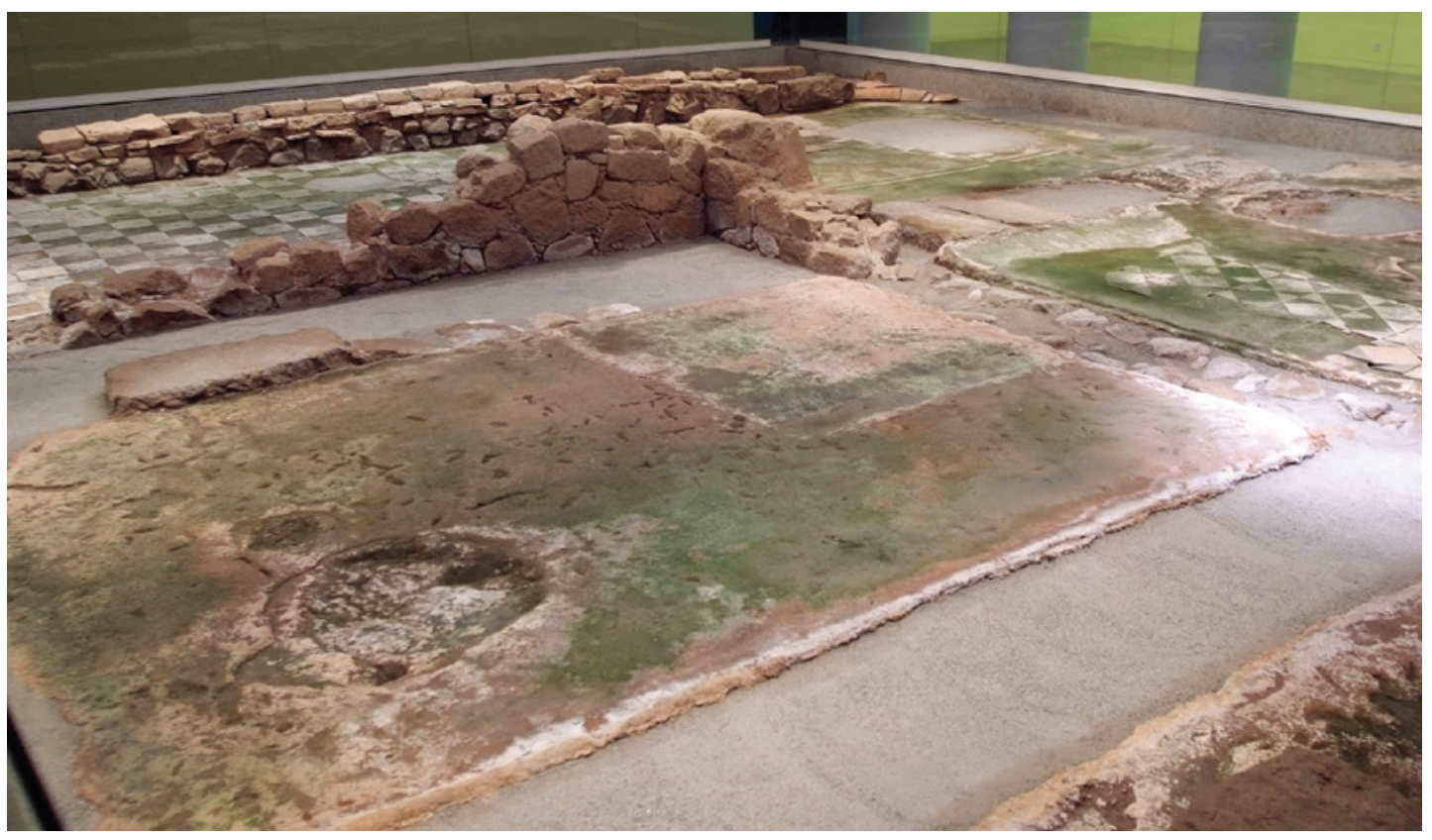

Figura 1 - Aspecto do mosaico com fungos, em 17/10/2003. (C) Fotos de Manuel Santos (AMDDS). 


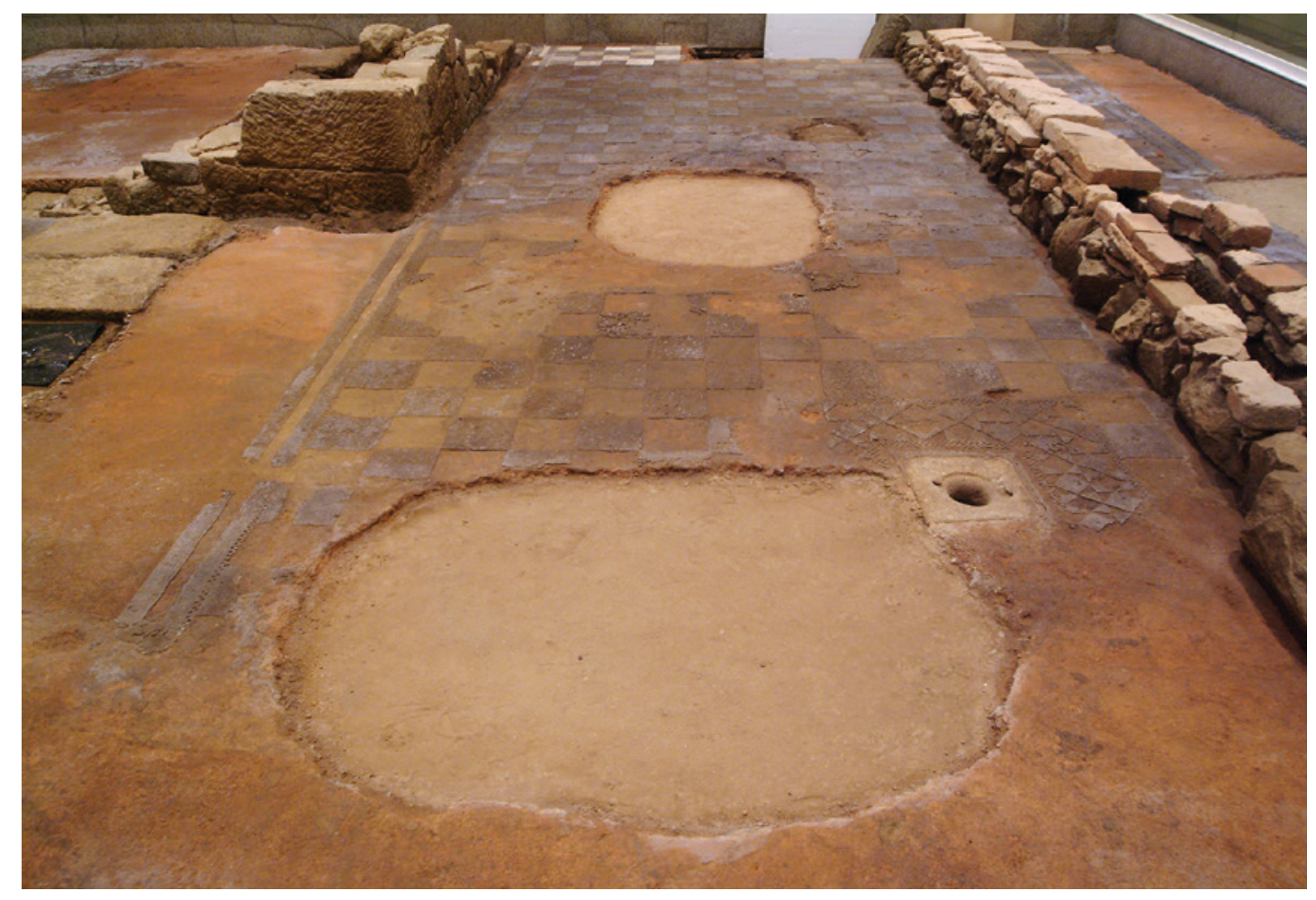

Figura 2 - Aspecto do mosaico depois de limpo para apresentação no espaço da cripta do Museu. (C) Foto de Manuel Santos (AMDDS)

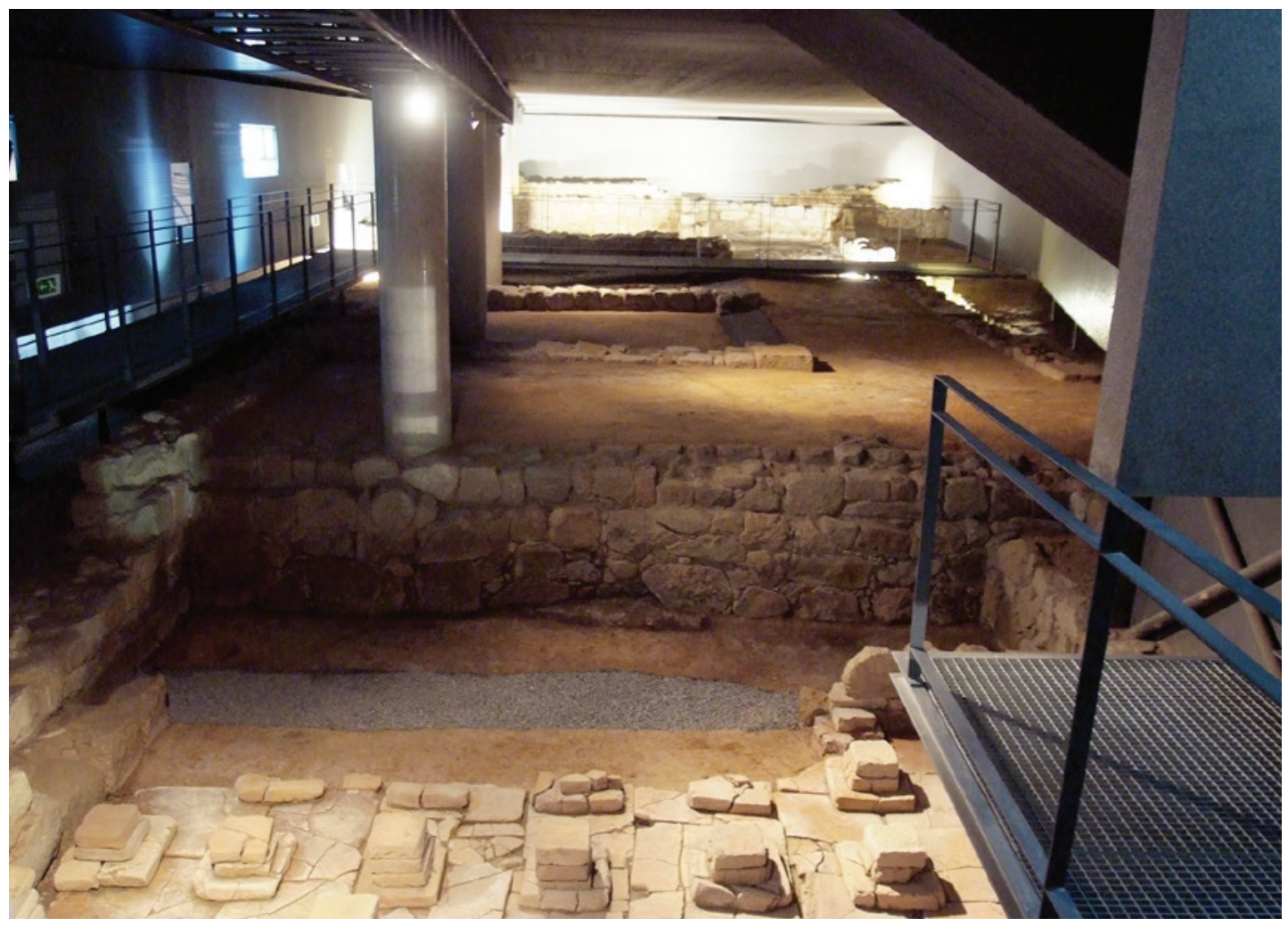

Figura 3 - Musealização dos vestígios arqueológicos na cave do edifício da Escola Velha da Sé. (C) AMDDS 


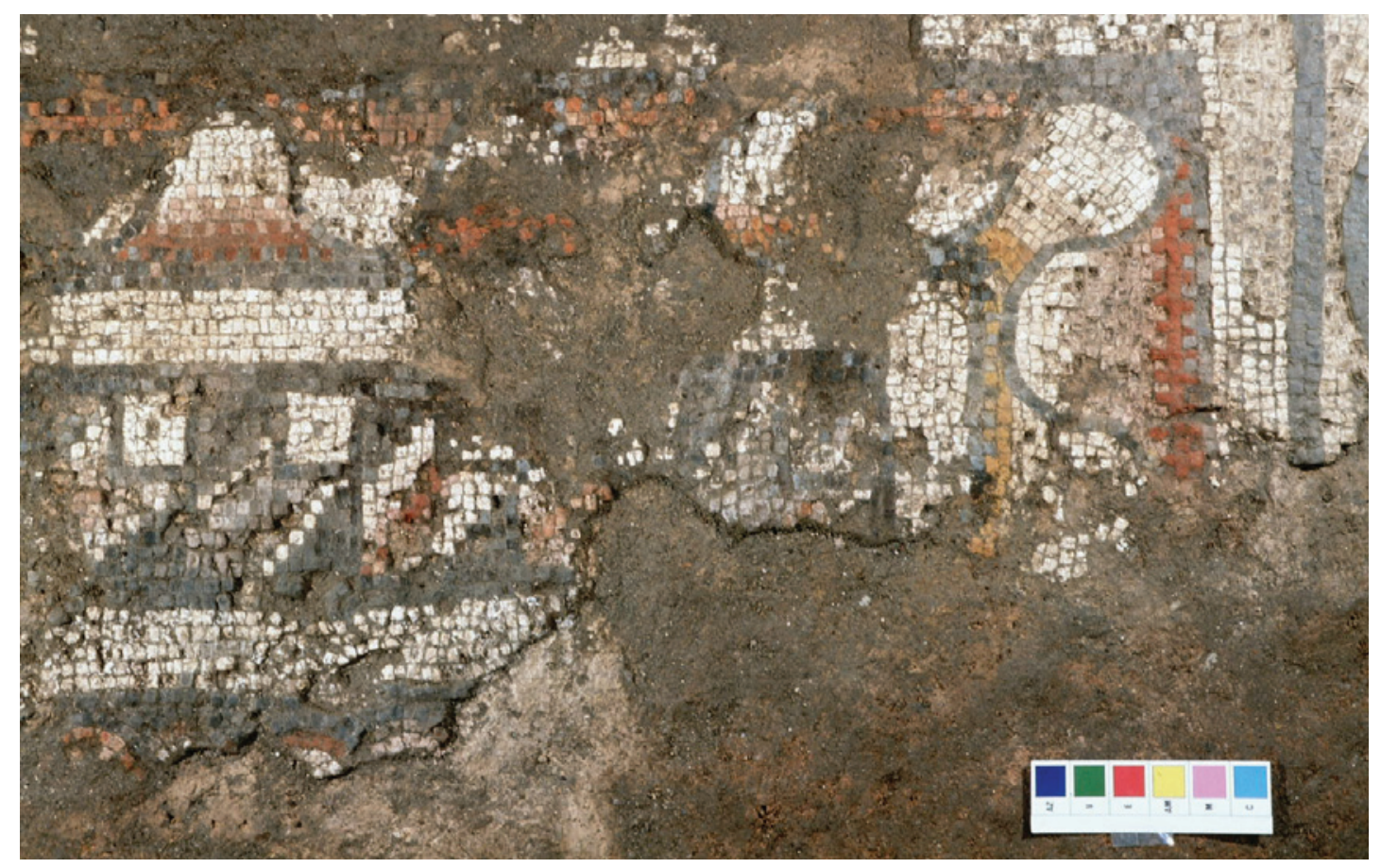

Figura 4 - Aspecto do mosaico da Casa da Roda. (c) AMDDS.

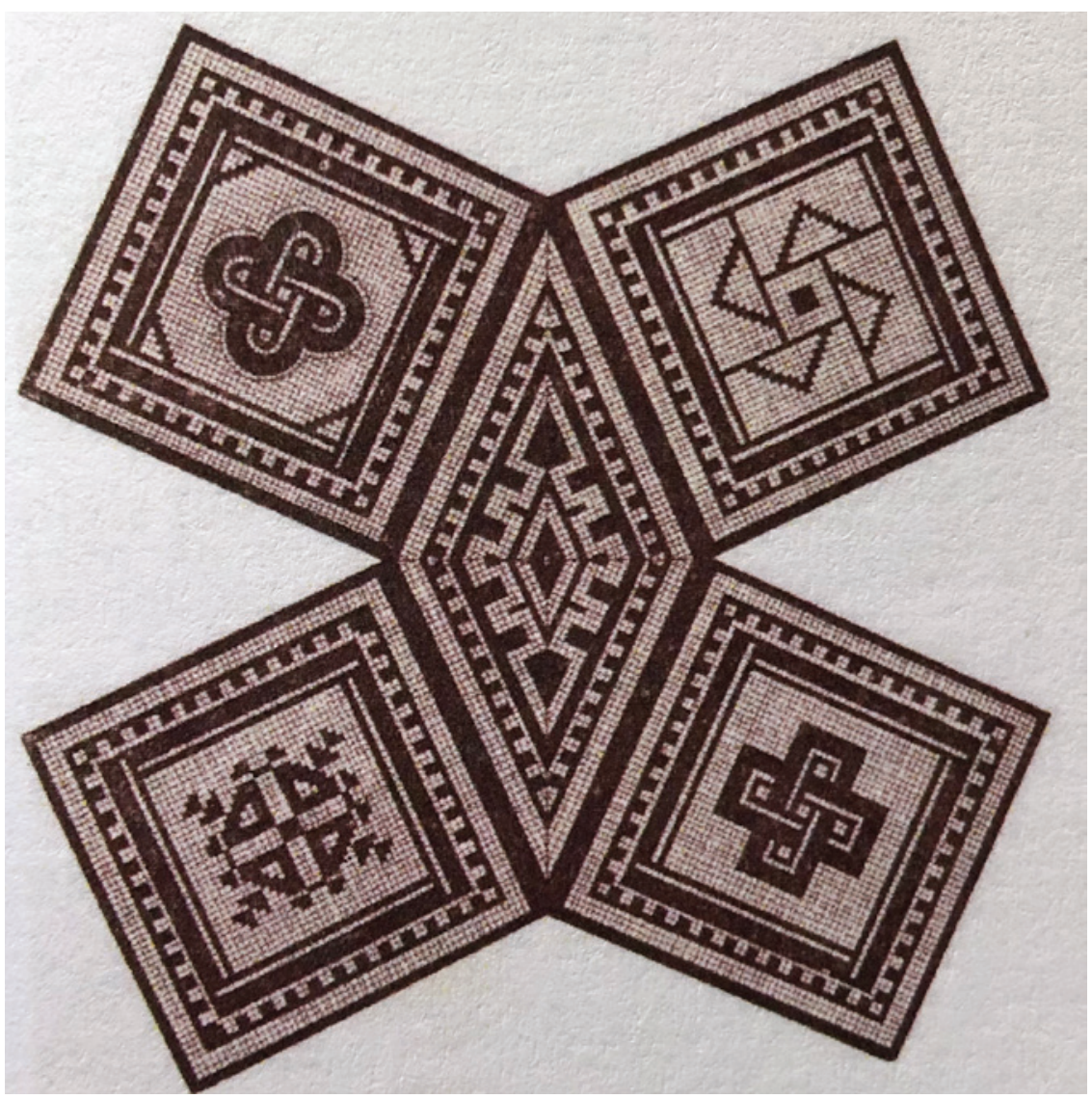

Figura 5 - Organização decorativa do mosaico de Vizela. Regueras Grande 2015, p. 283, Lam. 3a. 


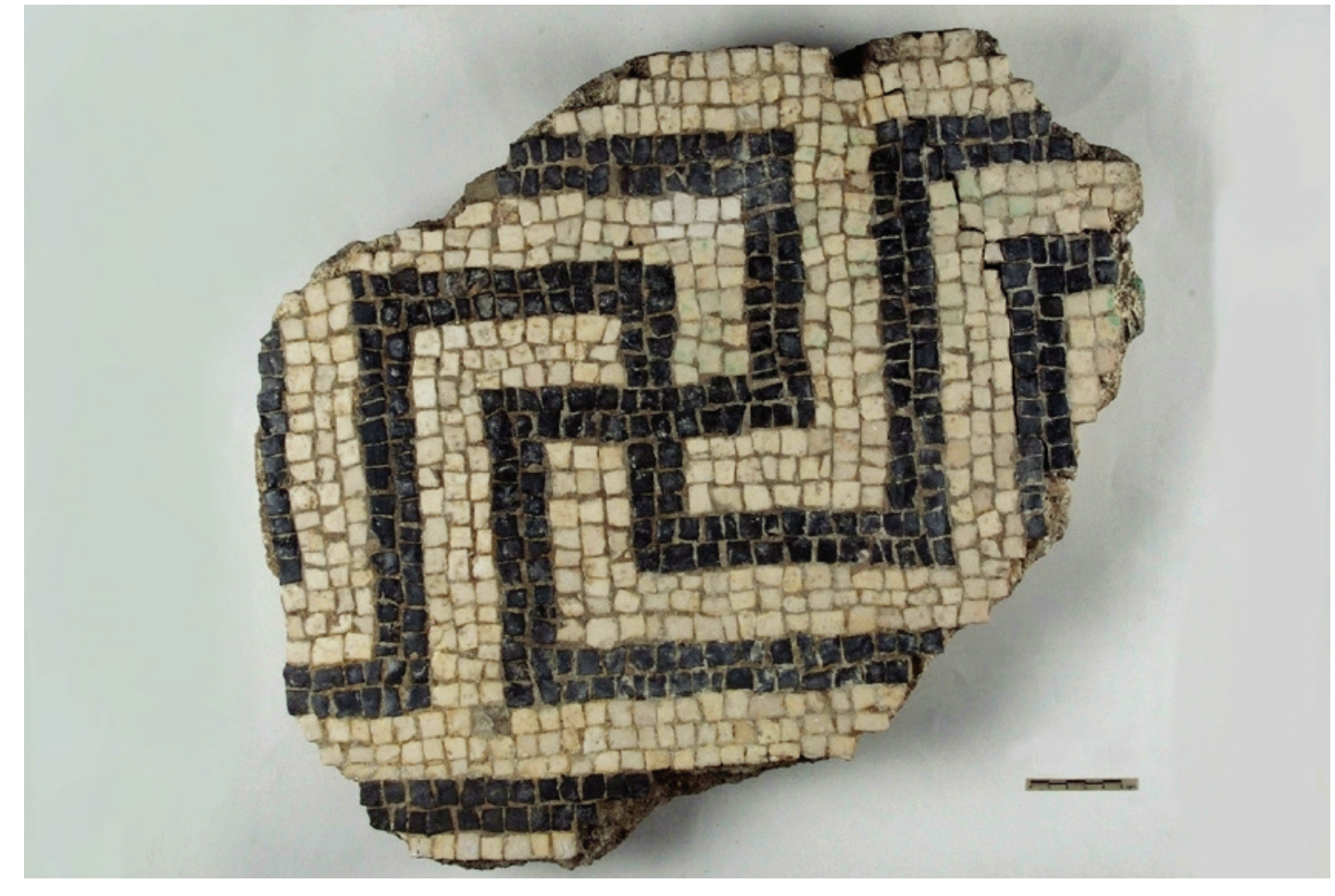

Figura 6 - Mosaico de Fontão de Antela, Lavra, Matosinhos. (c) AMDDS. 


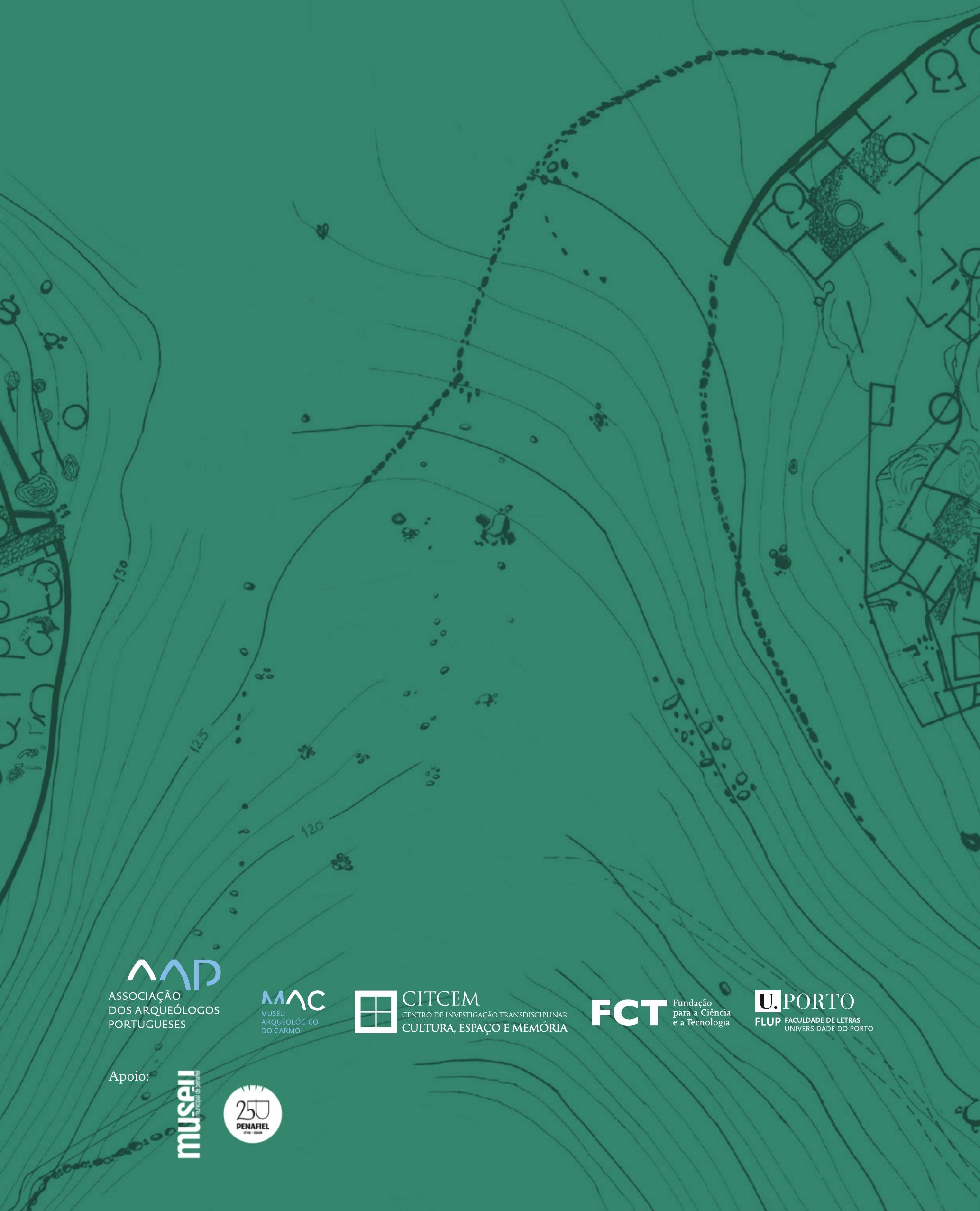

